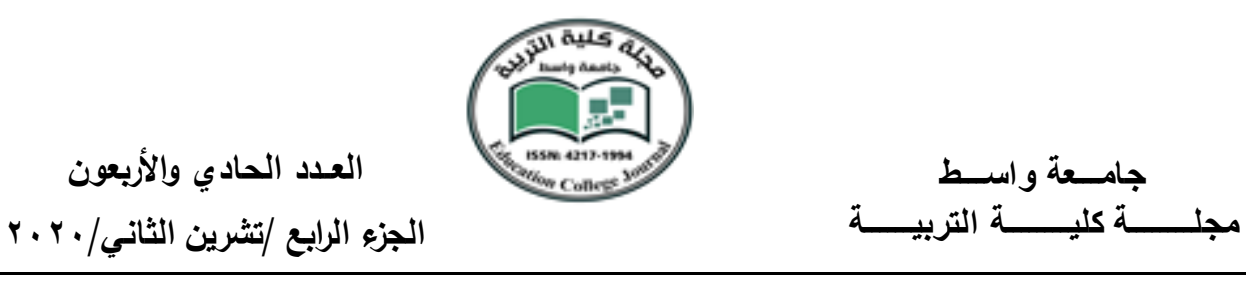

منظومة العبس في القرآن الكريم

داسة بلاغية

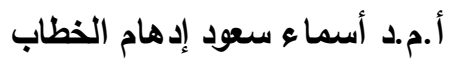

جامعة الموصل / كليّة الآداب/قسم اللغة العربية

asmaa.idham@yahoo.com

الملخص :

للكلمة القرآنية ولغتها فلسفة خاصة ترتبط ارتباطاً وثثقاً بإعجازه، فالقرآن الكريم يتناول من

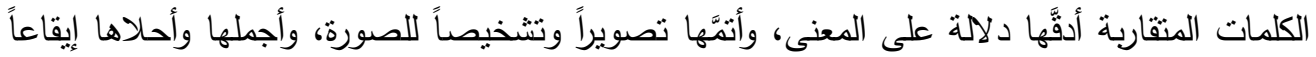

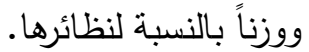

بينّا في شرح المعاني دقة التعبير القرآني للكلمة دون أخواتها، وبأنها مسوقة في موقعها المناسب

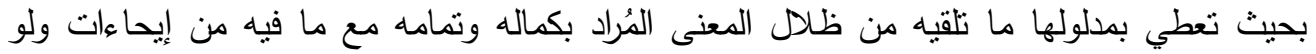

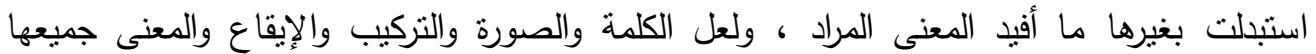

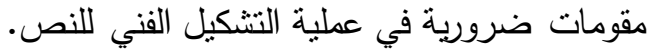
وردت الفاظ في القران الكريم تثل على الحبس ومراحله (حبس - سجن - امساك - توقيف - اثبات

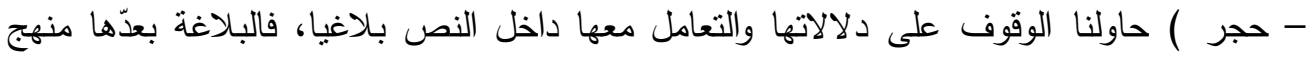

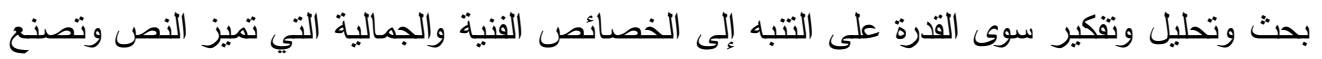

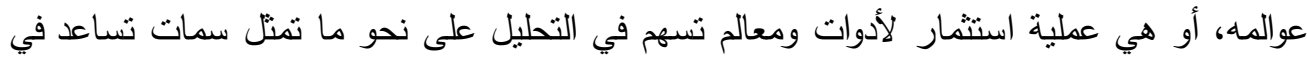
بناء مركزية النص اوادراك غناه وعمق بلاغته.

الكلمات المفتاحية : منظومة ، السجن ، بلاغية ، دراسة 
العدد الحادي والأربعون

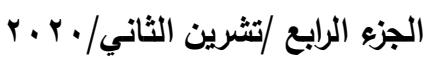

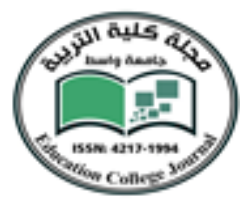

The matrix of imprisonment in the Glorious Quran

\section{Rhetorical study}

\section{Abstract}

The Quranic word and its language has a special philosophy that connected closely to its Inimitability, the Glorious Quran uses the most precise meaning of the proximate words, the most perfect ones in picturing and determining the image, and the most beautiful rhythm and balance comparing with the similar words.

We clarified in the meanings explanation, the precise of Quranic expression for the word other than the words, and it has been placed in its suitable context to show, in its connotation, the complete and perfect intended meaning with all the references it has.

And if a word has been replaced by another, it will not fit the intended meaning, may the word, the image, the structure, the image, the rhythm and the meaning all be the necessary factors in the process of the text technical forming.

There are many vocabularies occur in the Glorious Quran to refer to imprisonment and its levels: (habs = custody, sagn = prison, Emsak = constipation, tawqeef $=$ arrest, ethbat $=$ confirmation, hajr $=$ quarantine, and rebat $=$ bind), we tried not only to show its connotations but also to deal with it within the text rhetorically, because rhetorical, as a method of searching, analyzing, and thinking, has the ability to pay attention to the aesthetic and technical characteristics that characterize the text and make up its contexts, or it's an investigating process to the instruments and appearances that contribute in the analysis that represents helping features to build the unity of the text and

\section{System ‘Prison, rhetoric, study}


العدد الحادي والأربعون

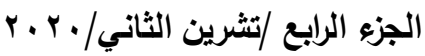

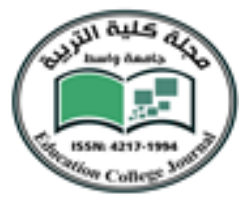

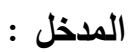

يعود تاريخ وجود الذنب والجريمة إلى بدء الخليقة اذ ارتبط وجودهما بوجود الإنسان ذاته، الذي ربما انساق في الكثير من الأوقات إلى اطماعه وتحقيق شهواته وهفواته التي لاتتنهي لنلك فان

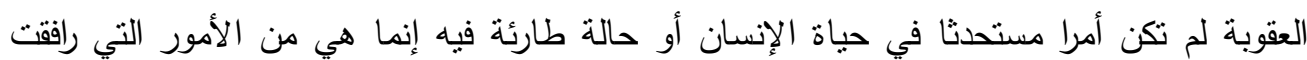
الإنسان منذ ولادته . العانه

وقد كان الاسلام من خلا تشريعاته وتعاليمه أحرص مايكون على صون كرامة إلإنسان والإعلاء من قدره، بل إنه اعتبر أنَّ حرمة دم المسلم أعظم عند الهه من هدم الكعبة الثريفة؛ لهذا فقد الهان

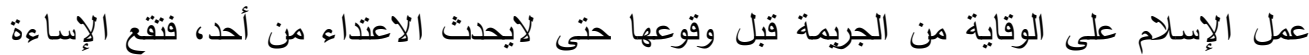
والضرر على المعتدى عليه ممّا يسنوجب معاقبة المعتدي .

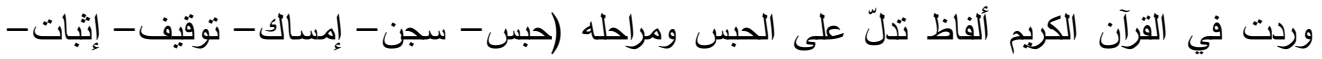
حجر ) ، حاولنا الوقوف على دلالاتها، فللكلمة القرآنية ولغتها فلسفة خاصة ترانه ترتبط ارتباطاً وثيقاً

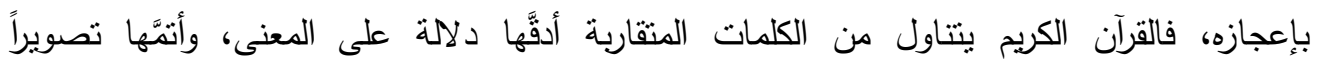
وتشخيصاً للصور ، وأجملها وأحلاها إيقاعاً ووزناً بالنسبة لنظائرها.

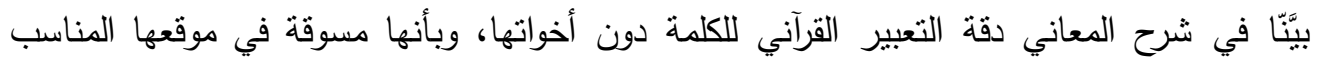
بحيث تعطي بمدلولها ما تلقيه من ظلال المعنى الئراد بكماله وتمامه مع ما فيه من إيحاءات، ولو لواني استبدلت بغيرها ما أفيد المعنى المراد ، ولعل الكلمة، والصورة، والتركيب، والإيقاع، والمعنى، جميعها

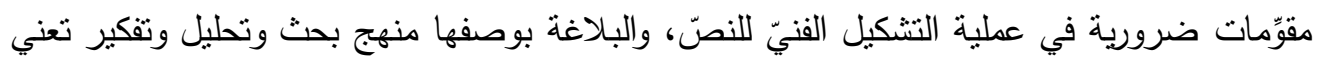

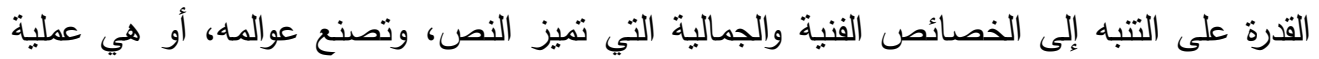

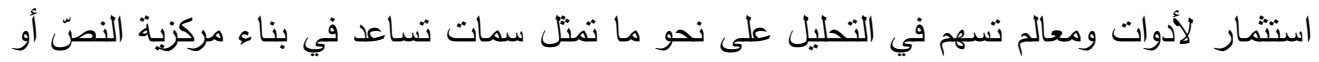

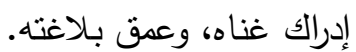

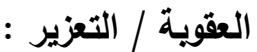

العقوبة اسم مصدر من عاقب يعاقب عقابا معاقبة ، وهي الجزاء على الفعل السيئ(1) ، أما اصطلاحا فهي: الجزاء المقدر على مخالفة الشرع بانتهاك حق الله تعالى، حدّا كان أو كفارة أو تعزيراً فهي ردّ فعل المجتمع تجاه العدوان الذي وقع عليه ، وإذ تعيد العقوبة النوازن إلى ميزان الحقوق

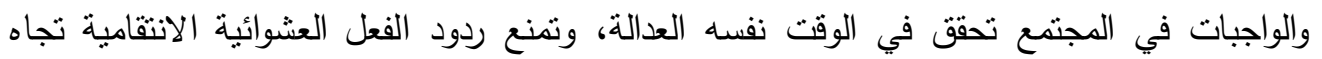

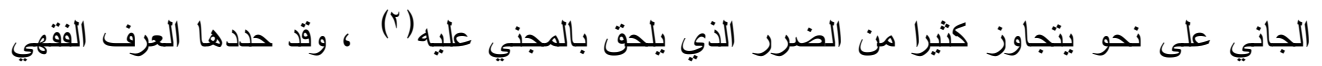

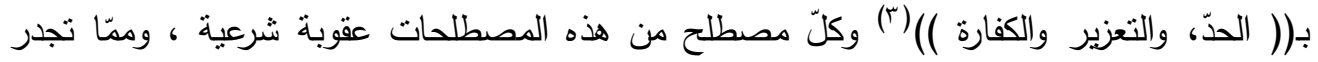


العدد الحادي والأربعون

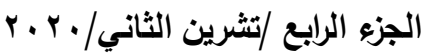

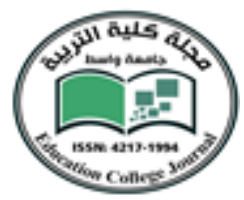

الإثارة إليه أنَّ الثريعة الإسلادية حافظت على النوازن الذي يجب أن تقوم عليه العقوبة من خلال حفظها للنسبة بين الجرم والجزاء ، وهذا ما لم تلتقت إليه القوانين الوضعية ، فالثريعة الإسلامية الإنساية

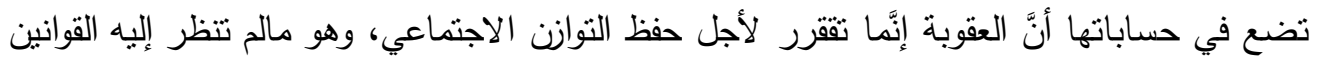
الوضعية بما هو، بل اعتبرته جانبا من الجوانب التي قررت العقوبة لأجلها.

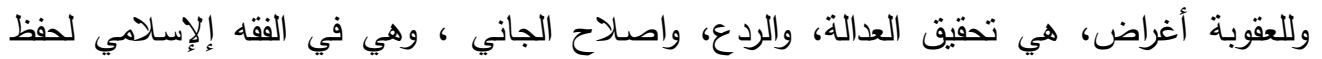

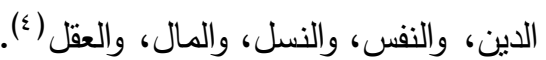

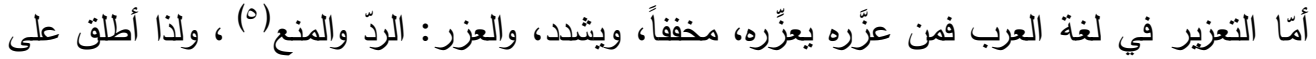

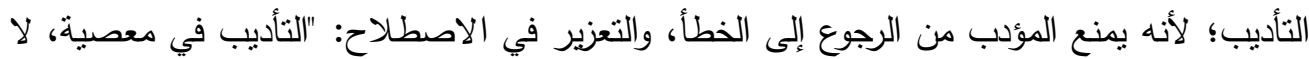

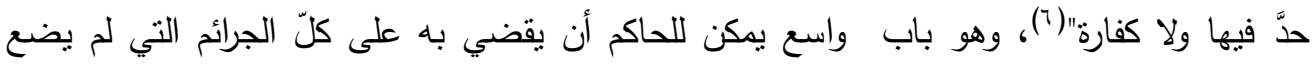

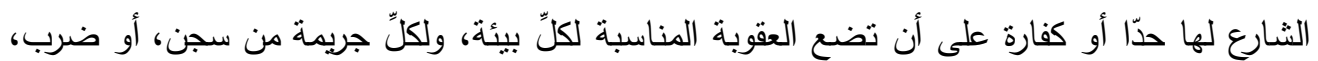
أو نفي، أو توبيخ، أو غير نلك (( يعزر الرجل بوعظه وتوبيخه والإغلاظ له ... وقد يعزر بعزله عن ولايته ... وقد يعزر بعزله عن ولايته ... وقد بعزر بترك استخدامه في جند المسلمبن، وقد يعزر

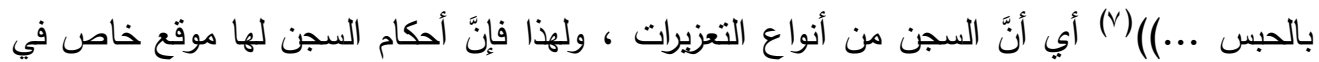
الفقه إلإسلامي.

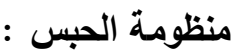
النظم لغة : التاليف ، نظمه ينظمه نظما ونظاما ... وكلّ شيء قرنته بآخر ، أو ضمدت بعضه إلى بعض فقد نظمته ، وناظم ومنظوم ، والنظم مانظمته من لؤلؤ وخرز وغيرهما ... والانتظام ، وكلمة النظم تطلق على الثيء المنظوم من باب الوصف بالمصدر مبالغة وتخفيفًا .

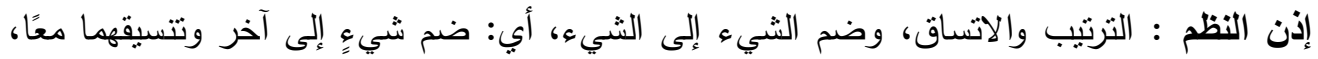
فلا يقال لأمرين أو أكثر: نظم أو منظومان إلا إذا رتبا على نسق معين، ولائ يقال لأمر عشوائي: إنه نظم أو منظوم. والمنظومة : المرتبة والمضموم بعضها إلى بعض ، ونسنطيع القول إنها تتبر إلى تللك العطليات المنظمة منطقيا، ثُ تجزئتها إلى عناصر ، وإيجاد العلاقات المنبادلة بينها. والحبس والسجن بمعنى واحد عند الفقهاء، فهم يطلقون الحبس والدحبس والسجن على الدكان الذي

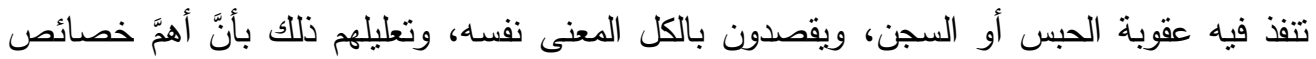

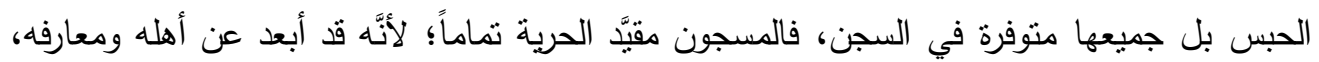


العدد الحادي والأربعون

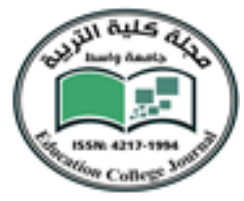

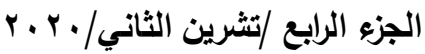

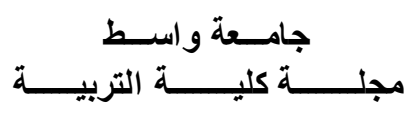

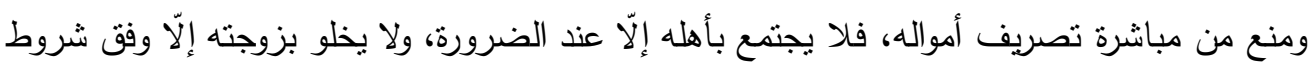
معينة، ولا يتمكن من الخروج لتأدية العبادات وغيرها من الواجبات إلى غير نلك من القيود.

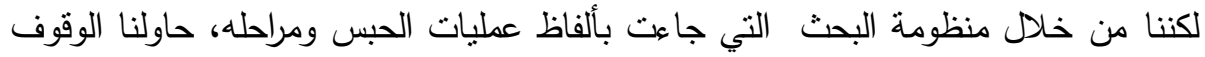

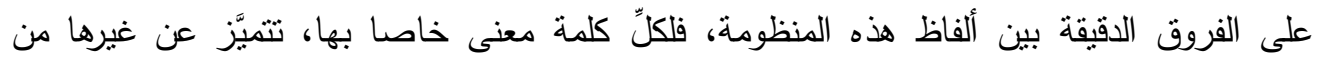
كلمات المنظومة، فهناك من يظن أنَّ هذه الكلمات مترادفة في معناها، ولكن إذا ما تأملنا استعمالاتها

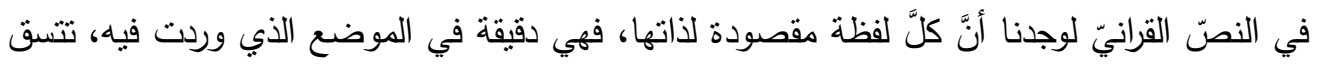

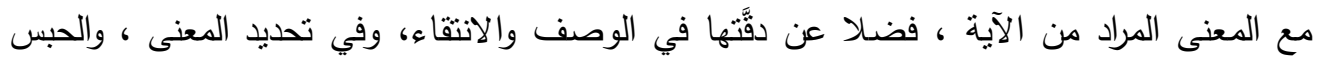

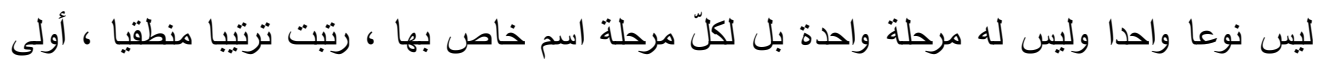

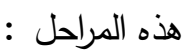

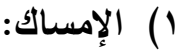

\begin{tabular}{|c|c|c|c|}
\hline السورة & رقمها & الاية & اللفظة \\
\hline البقرة & rrq & 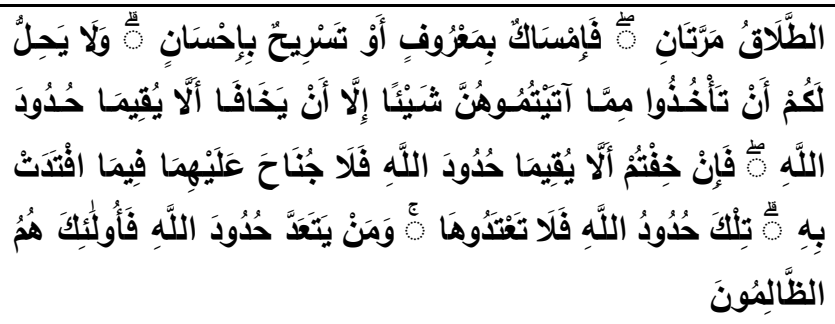 & فامساك \\
\hline البقرة & rTI & 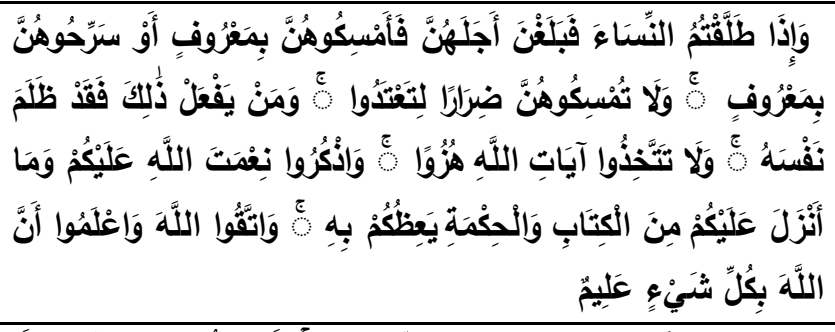 & فامسكوهن \\
\hline النحل & 09 & 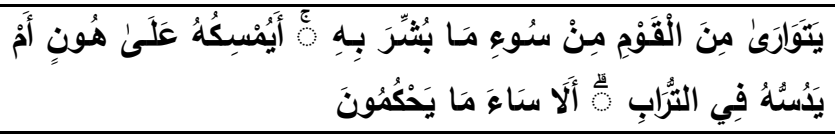 & \\
\hline الطلاق & r & 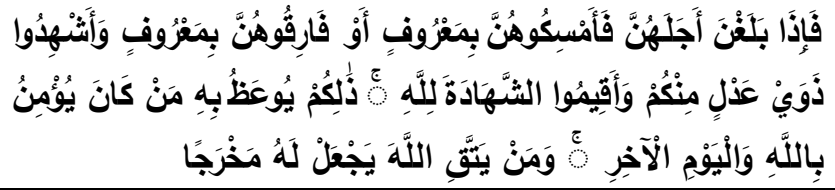 & فامسكوهن \\
\hline
\end{tabular}


العدد الحادي والأربعون

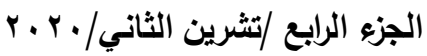

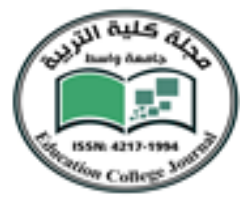

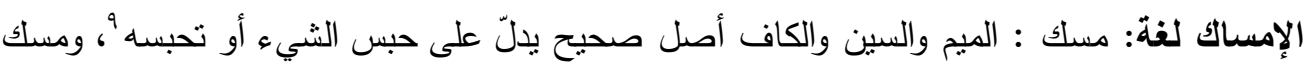

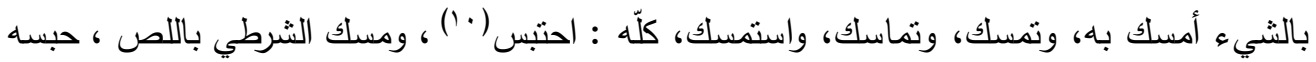

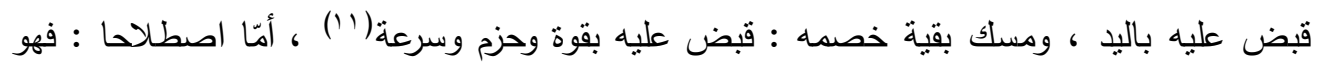

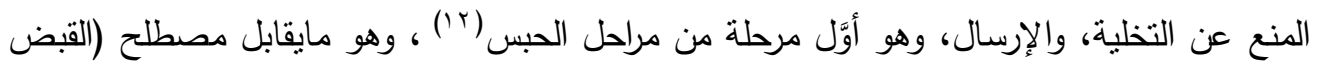

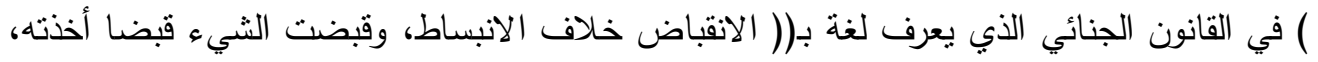

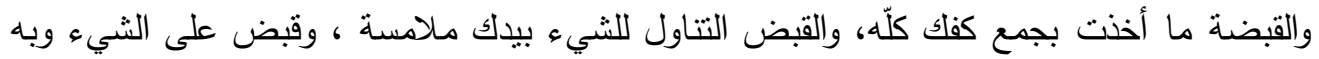

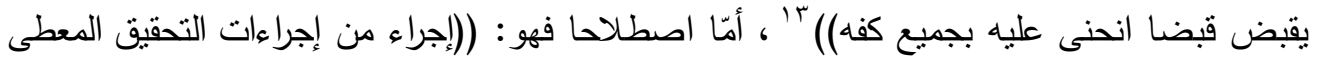

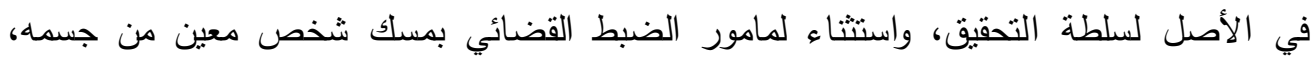

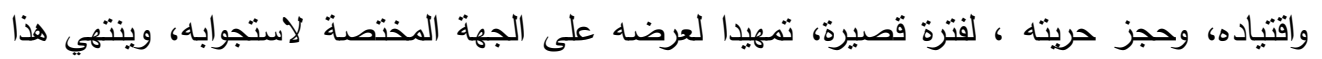

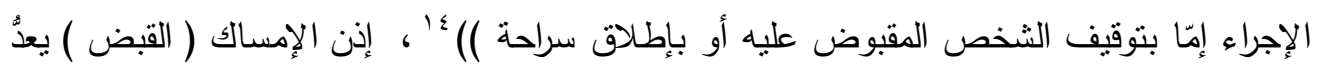

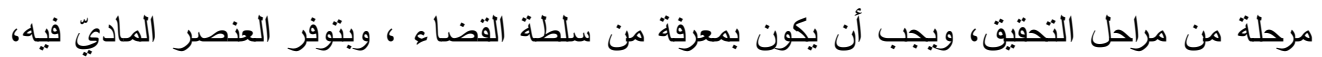
المتمتل بالإمساك والاحتجاز للمقبوض عليه من قبل السلطة المختصة بصرف النظر عن خضوع

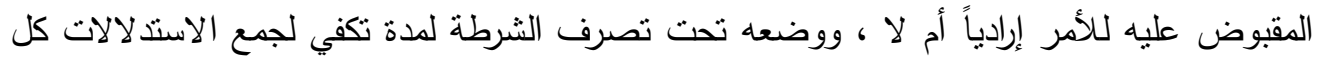
ذللك تمهيدا لاستجوابه . وقد ورد الامساك في القران الكريم في آيات الطلاق:

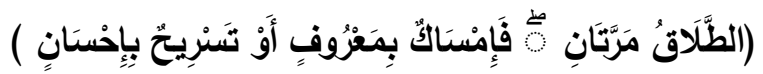

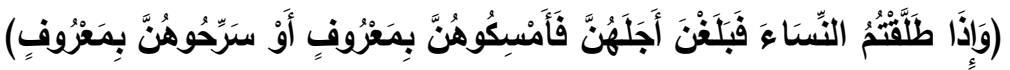

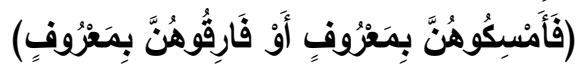
اذ قامت منظومة الطلاق على ثنائيات متقابلة :

\begin{tabular}{|c|c|}
\hline تسريح بإحسان & فإمساك بمعروف \\
\hline سرحوهن بمعروف & امسكوهن بمعروف \\
\hline فارقوهن بمعروف & امسكوهن بمعروف \\
\hline
\end{tabular}

جاءت هذه الآيات في أحكام الطلاق وآدابه ، ولم يسلك الحق في بيانها الأسلوب التقريري الجاف

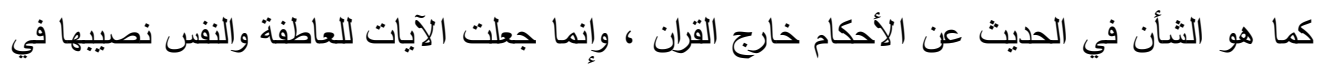

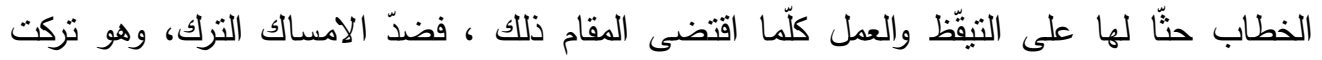

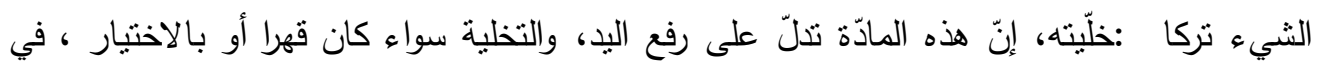


العدد الحادي والأربعون

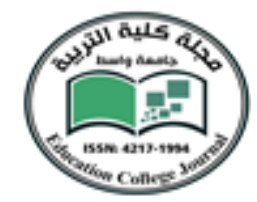

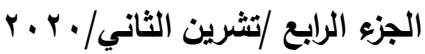

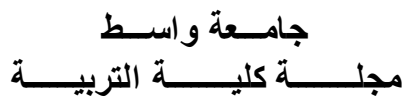

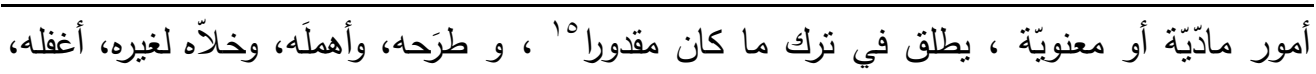

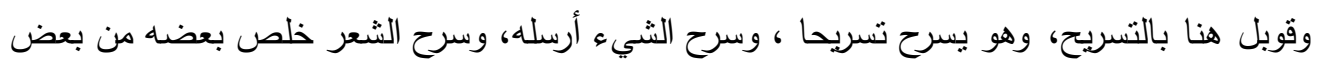

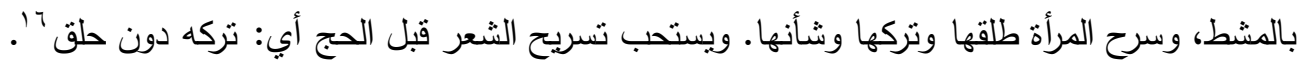

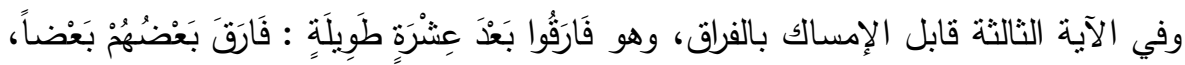

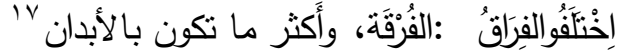

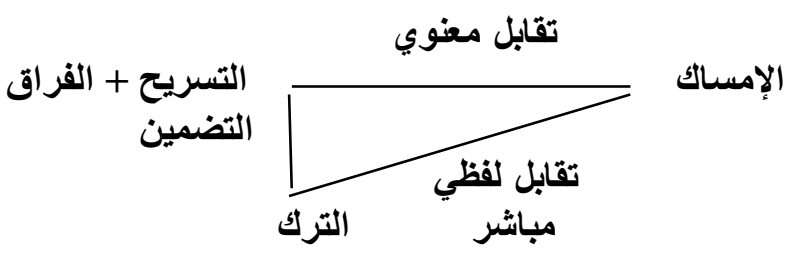

ولدى أخذ الإمكانات الدالية لكلمة ( التسريح والفراق ) بالاعتبار نلحظ الكلمتين

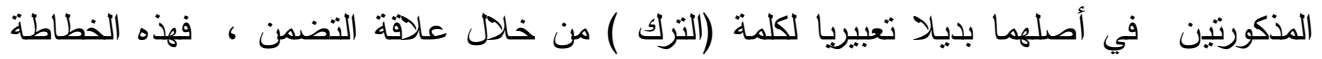

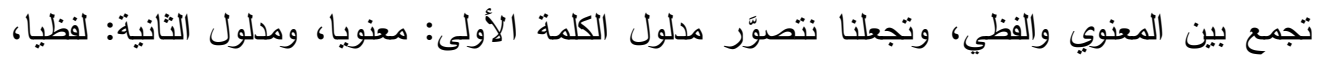

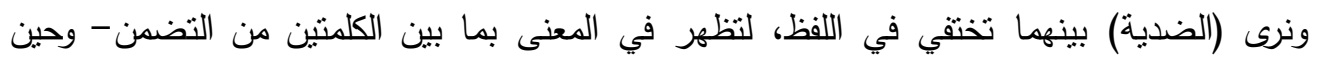

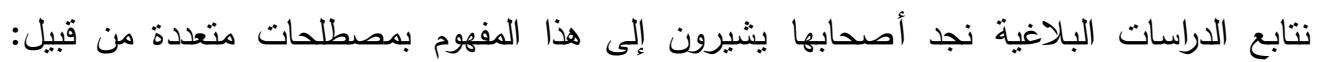

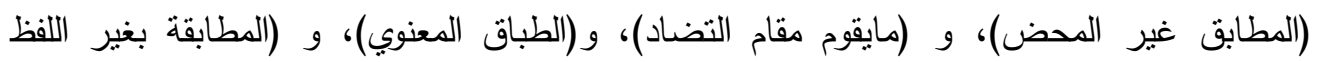

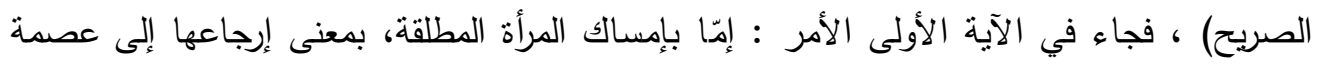

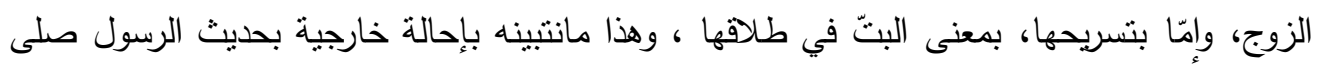

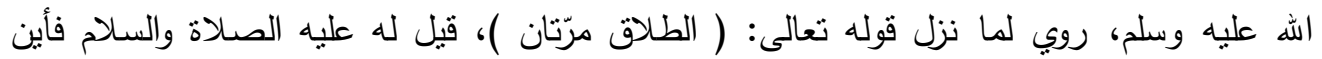

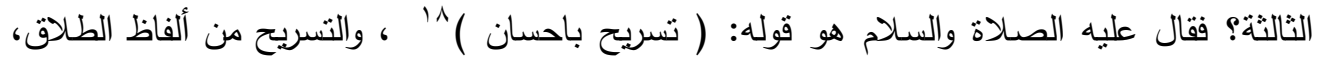

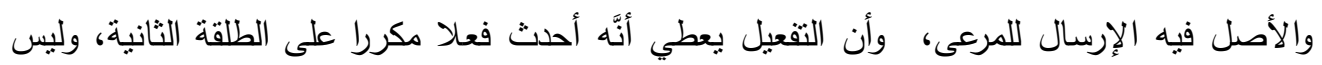

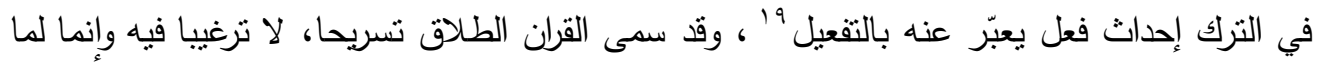
يجب على المسلمين من حسن المعاملة، وجمال الكيفية التي يتوقعون بها الطلاق اذا اقتضته لفئه الضرورة ولا بديل له .

جاءت الآية في سياق النهي عن مضارّة النساء، وتحريم أخذ شيء منهن، ما لم يكن منهن

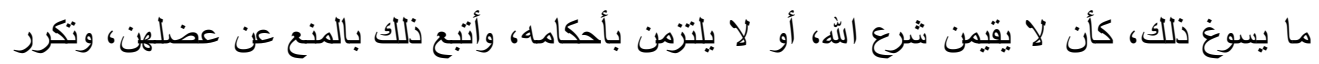

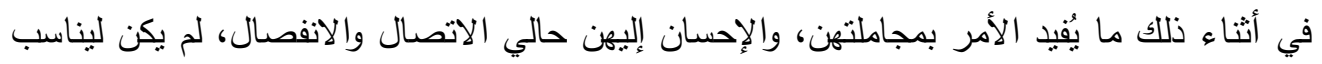


العدد الحادي والأربعون

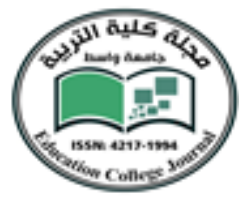

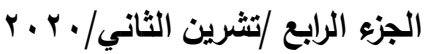

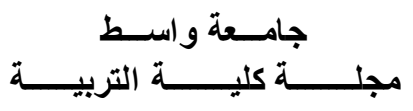

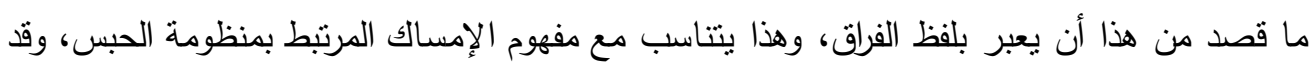
روعي في هذه الآيات كلّها مقصد التلطف، وتحسين الحال في الإمساك والافتراق. ومن الملاحظ في هكذا أنماط خطابية هو اتسامها بالتكثيف الدلالي بحيث يبدو كأنَّه قناة للتفاعل الحي بين القيمة التخاطبية والقيمة البلاغية الجمالية، وأنَّ توافر الخطاب على هذه السمة يخرج بالنسق الإخباري التقريري إلى سياق فعله وتاثيره بالمتلقي من خلال التحذير، فالتطليق حكم شرعي، والحذر من أن نطلّق مرّتين لأنه لن يكون للك بعدها إلّا خيارا واحدا: إمّا الامساك بحسن العشرة، وإمّا التسريح الجميل، فلا رجعة بعد الثالثة ، وقد اتضحت التجليات الدلالية من خلال بيان الأواصر العلائقية القائمة بين الحث اللغوي والمرجعية الخارجية من طرف، وبين المرسل والمتلقي

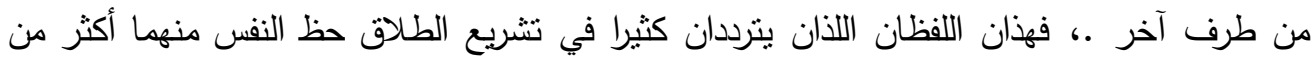

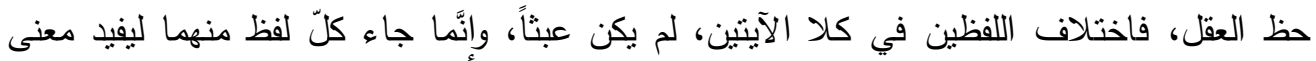

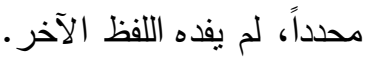

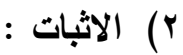

\begin{tabular}{|c|c|c|c|}
\hline السورة & رقمها & الآية & اللفظة \\
\hline الانفال & $r$. & 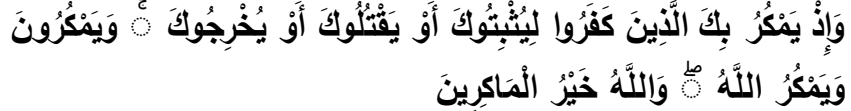 & ليشبتوك \\
\hline
\end{tabular}

الإثبات : هو تاكيد الحق بالدليل، يقال: أثتب حجته أي: أقامها وأوضحها ... فطعنته فاثتته أي: حبنه وجطلته ثابتا في مكانه لايفارقه، وأثنت فلان فهو مثثت إذا اشتد ت به علته أو أثنتته جراحه

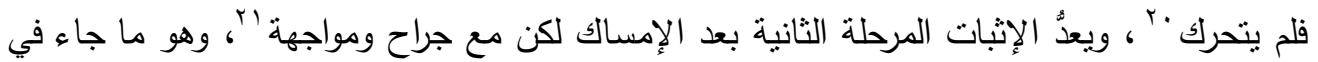
قوله تعالى، فالتقييد يكون بأن تمنع المتحرك عن الحركة، أو أن تقيّّا المتحرك نفسه فتحدد مجال

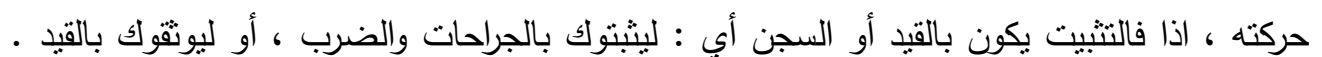

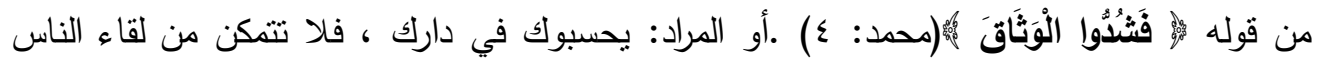
ومن طوعتهم إلى الدين الحق، فجاهت ليتبتوك في النص بمعنى ليمنعوك من التصرف بالحبس،

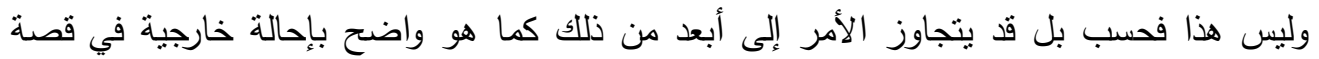
قريش ومشاورتهم في دار الندوة في أمره (ص) حين اجنمعوا للتشاور في ذلك بل بدار الندوة في الأيام 
العدد الحادي والأربعون

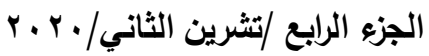

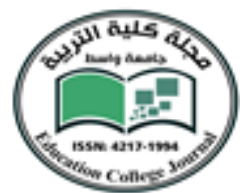

الأخيرة قبل الهجرة فقال أحدهم : إذا أصبح فاثثتوه بالوثائق، وسدّوا عليه باب بيت غير كوة تلقوا منها الطعام ، وقال أبو جهل : أرى أن تأخذ من كلّ بطن من قريش فتى جلدا، فيجتمعون، ثم يأخذ كلّ التّ واحد منهم سيفا، ويأنون محمدا في بيته، فيضربونه ضربة رجل واحد، فلا نقار بنو هاشم على قتال

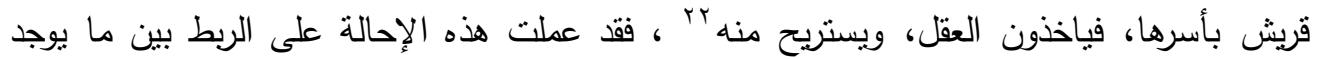
داخل النص، وما يتصل به من خارجه، وكان دورها علية تعاونبة؛ لأنها تستهدف تمكين المخاطب من التعرف على الذات المقصودة من قبل قريش، ويتم ذلك عن طريق إمداد المخاطب بكل المعلومات التي يمتلكها المتكلم عن هذه الذات أو الذوات، فنحن أمام ثلاث خيارات ترددية :

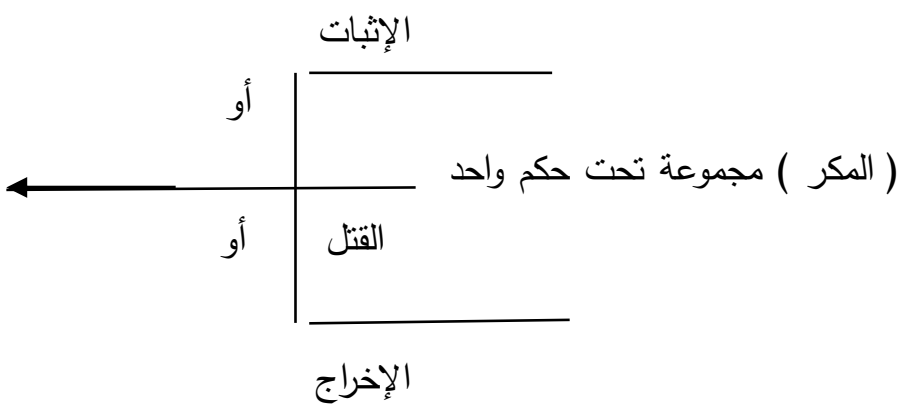

نستتتج من ذللك أنَّهه حينما تتشكل مورفيمات النسق مع طائفة من الوحدات المعجمية المرصفة أفقبا بعلاقة الربط التركيبية تتكون نوليفة خطابية ممندة ومندرجة في نتعاقب المفردات فيها، وهذه التوليفة شبيهة بما يسمى في علم الرياضيات دالة الدالة الافراد، فانفتاح الخطاب النسقي في

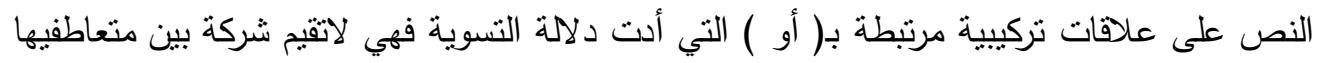
في الحكم ،بل تتبته لأحدهما، ولاتعين ذلك الواحد ، فهي تسوي بينهما في استقال كل واحد منهما

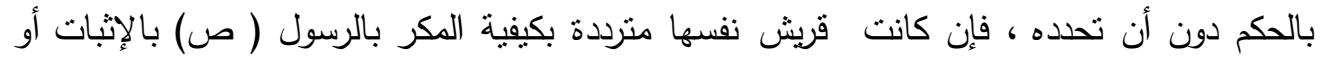

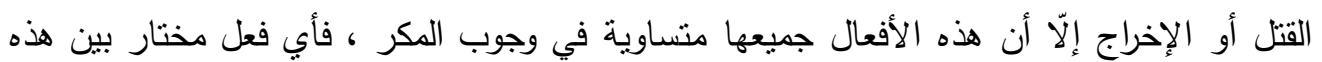

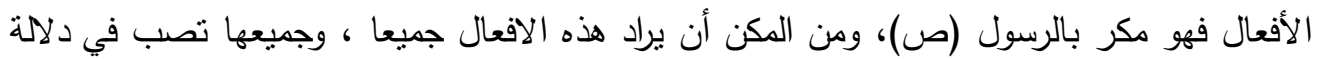

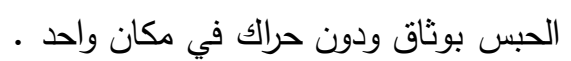

وجاء النعبير بالمضارع في ( يثنتوك، ويقتلوك، ويخرجوك )؛ لأنها أفعال مستقبلية بالنسبة وفية

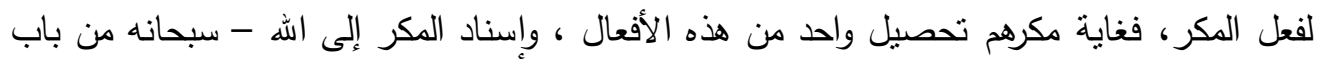

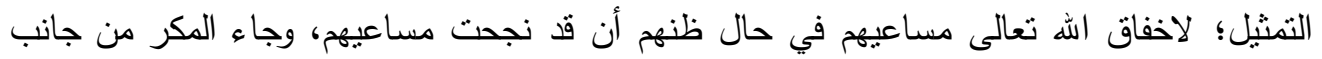


العدد الحادي والأربعون

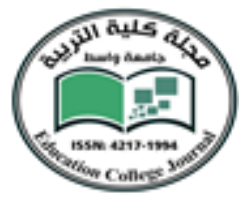

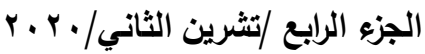

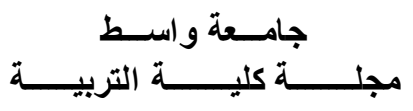

الحق - سبحانه بصيغة اسم الفاعل ( الماكرين ) الدالة على الحث وحاملة لبعض معنى المكر، ولكن مع دلالتها على الحدوث أي التغيير .

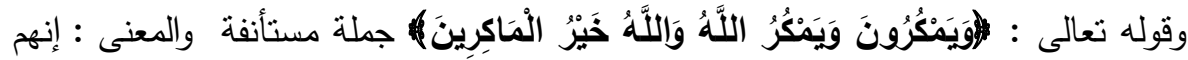

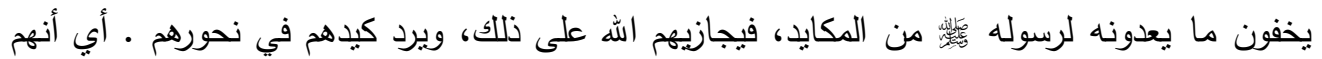

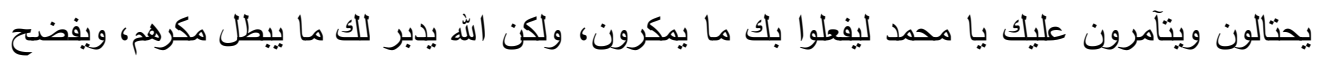

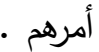

إنها صورة مفزعة، فأين هؤلاء البشر الضعاف من قدرة الله الجبار، القاهر فوق عباده،

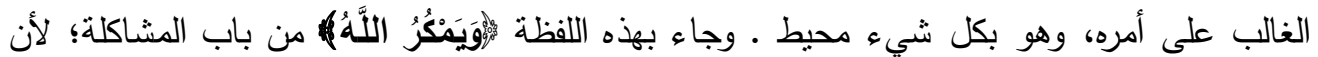

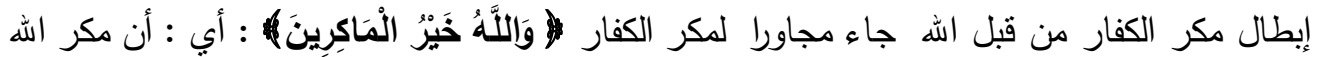

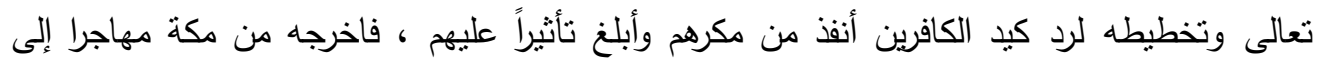

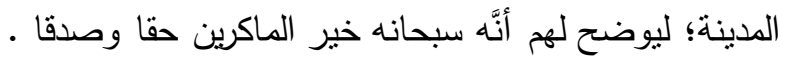

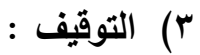

\begin{tabular}{|c|c|c|c|}
\hline 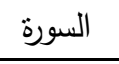 & رقمها & الاية & اللفظة \\
\hline الانعام & TV & 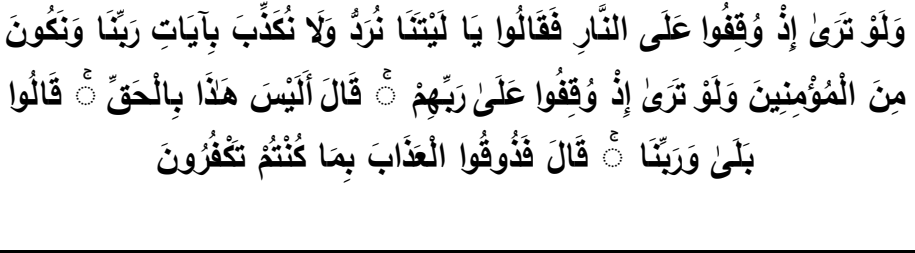 & 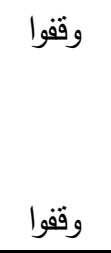 \\
\hline سبا & 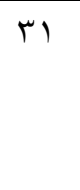 & 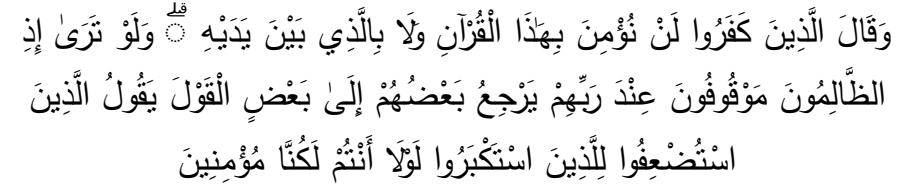 & موقوفون \\
\hline الصافات & $r \varepsilon$ & 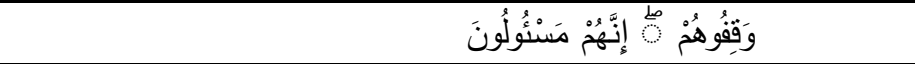 & وقفوهم \\
\hline
\end{tabular}

وقف : الواو والقاف والفاء : اصل واحد بدل على تمكث في شيء ثم يقاس عليه .....ومنه الوقف

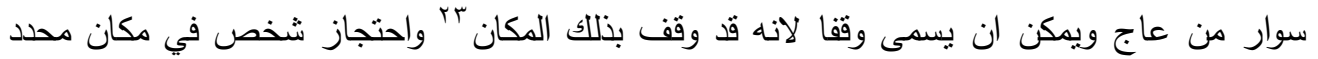

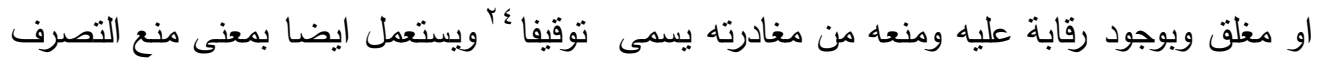
بالشيء ولايخرج معناه الاصطلاحي عما ورد في اللغة فهو : ايداع المتهم السجن فترة التحقبق كلها 
العدد الحادي والأربعون

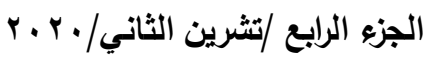

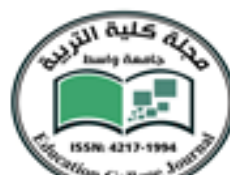

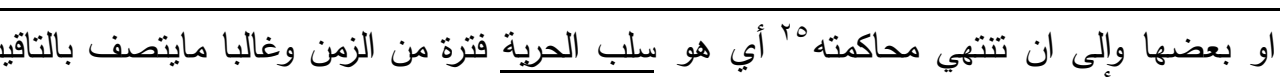
تستوجبه مصلحة التحقيق ، ولايسمى التوقيف حبسا حتى لايختلط الامر بالحبس كعقوبة .

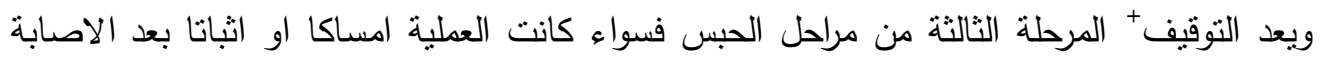
بجرح يعيقه من الفرار يوضع الممسوك في التوقيف ، فتوقيف المتهم يعني تقييد حريته قبل صدور الحكم بادانته وهذا مانجده في عطية النوقيف في سورة الانعام وتوقيف الظالمون في سورة سبا والصافات والاتفاق منذ البدء ان الكلام في الايات الاربعة عن مكان واحد يوم القيامة (عند الحشر)

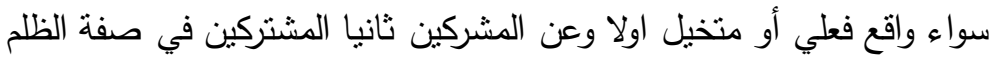
الظالمون = المشركون

فضلاً عن ان الايقاف ( النوقيف) في هذه النصوص هو جمع بين المشركين والذين دعوهم إلى الاشراك بليل قوله (( يوم نحشرهم جميعا ثم نقول للذين اشركوا مكانكم انتم وشركاؤكم ......)) سورة يونس + ازواجهم بدليل قوله تعالى : (( احشروا الذين ظلموا وازواجهم وماكانوا يعبدون )) سورة الصافات

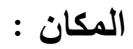
المحر عند البعث ( تثبيه = $=$ جنى ذنبا فقبض وقفوا على ربهم عليه فوقف بين يدي ربه - سيده للسؤال وبذللك تظهر

مزية التعبير بلفظ ( ربهم ) دون اسم الجلالة =

موقوفون عند ربهم عليه قانون اصول المحاكمات الجزائية العراقي المادة الجيات

r Iا والمادة 9 من العهد الدولي الخاص

وققوهم انهم مسئولون توقيف المتهم يعني تقييد حريته - قبل صدور

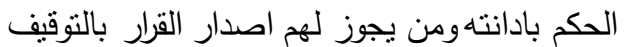

حصرا قضاة التحقيق 
العدد الحادي والأربعون

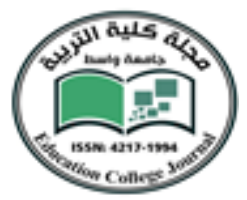

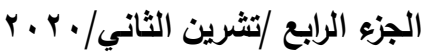

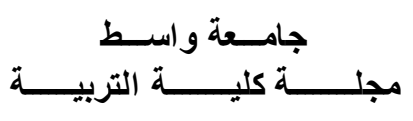

بدءا نقول المكان الجدير بالقراءة المقبوض عليه بواسطة الخيال لانه مكان متعدد الابعاد يثير بدوره

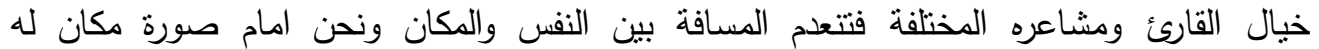
خصوصية وهوية - يوم الحشر فالمكان والحثث هما اللذان حدا صور اصحابه ونحن هنا امام مشهر من مشاهد القيامة التي يكون المشركون طرفا فيها جمعوا فسئلوا عن الهتهم فكذبوا على انفسهم واقسموا زورا وبهنانا انهم لم يكونوا في الدنبا مشركين وهذا مانصت عليه المادة س؟ من قانون اصول المحاكمات النافذ بقولها ((... ويدون افادة المجني عليه ويسأل المتهم عن التهمة المسندة اليه شفويا $\left.{ }^{r}\right)((. .$.

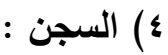

\begin{tabular}{|c|c|c|c|}
\hline 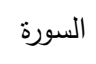 & رقمها & الاية & 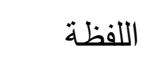 \\
\hline يوسف & ro & 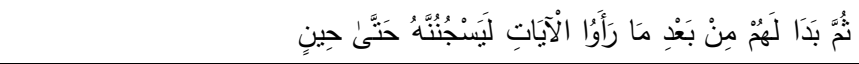 & ل ليسجننه \\
\hline يوسف & ro & 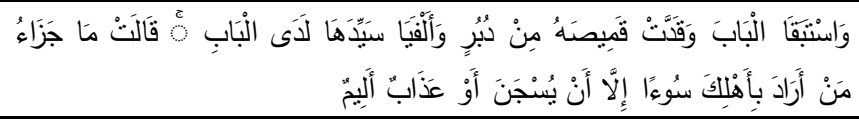 & يسجن \\
\hline يوسف & rr & 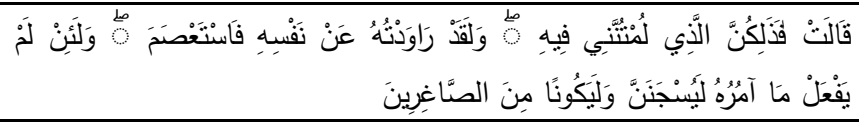 & 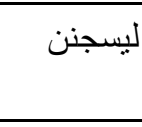 \\
\hline 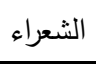 & rq & 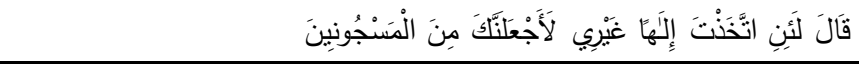 & 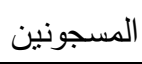 \\
\hline يوسف & r & 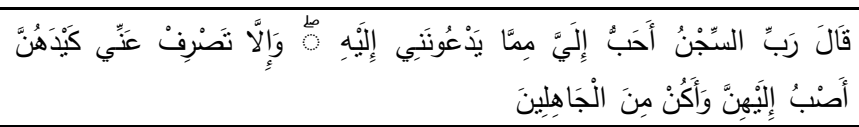 & السجن \\
\hline يوسف & $r$ & 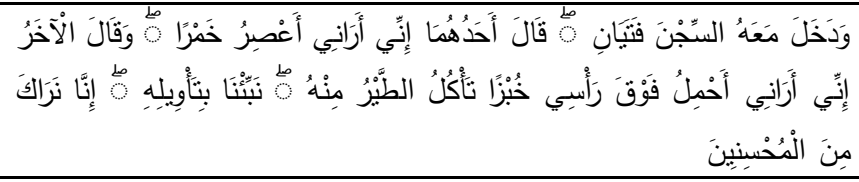 & \\
\hline يوسف & rq & 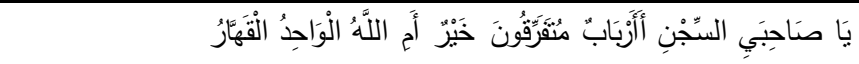 & \\
\hline يوسف & «) & 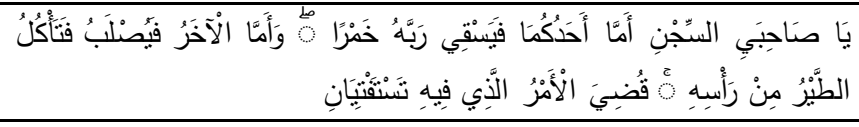 & \\
\hline يوسف & $\varepsilon r$ & 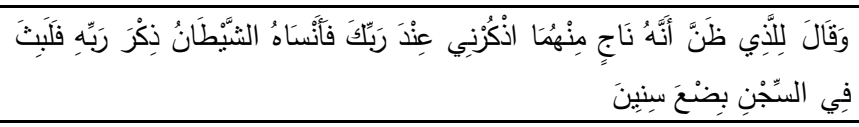 & \\
\hline يوسف & $1 \ldots$ & 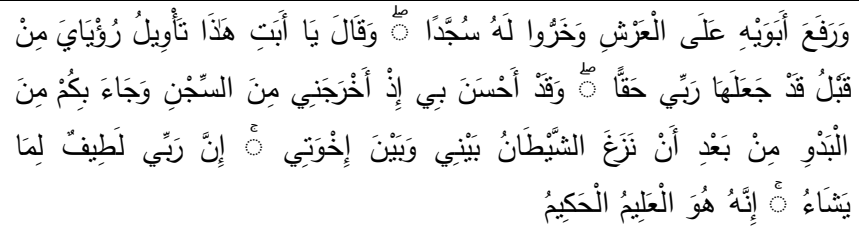 & \\
\hline
\end{tabular}


العدد الحادي والأربعون

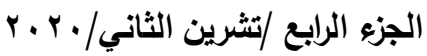

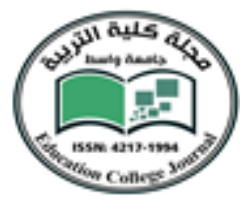

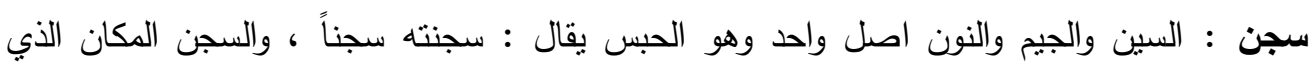
يسجن فيه إلإنسان او موضع الحبس ..... وهو الحبس لانه اذا كان ضربا شديدا اثبت المضروب كانه قد حبسه لَ، فكلمة السجن بفتح السين دليلاً على المصدر وبكسر السين دليلا على المكان

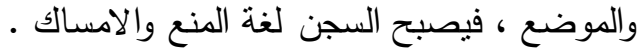
اما اصطلاحاً : فهو المكان الذي جرى اعداده وتهيئته لتنفيذ الاحكام على الاشخاص المتهمين المراد

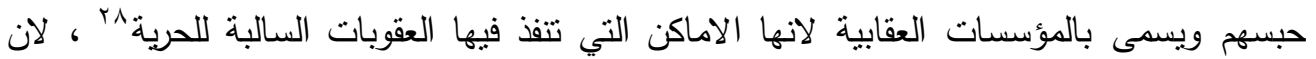

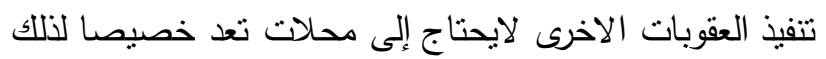
وقد ورردت لفظة السجن في تسعة مواضع في ايات القران الكريم في سورة يوسف بمناسبة

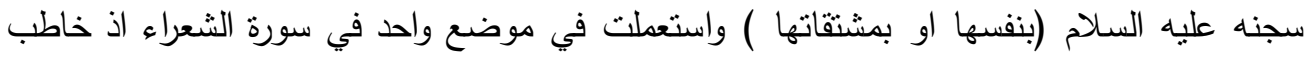
فرعون موسى عليه السلام مهددا اياه بالسجن وحكى هذا القول القران الكريم ، فالسجن بمعناه الواقعي كان موجودا في عصر موسى وفرعون حنى قبل ذلك اي في زمن يوسف والعزيز ، فكانوا يودعون المذنب والبرئ في السجن اذ بعض السجناء كان ييقى سنوات عديدة حتى باتي عليه النسيان . فقصة يوسف عليه السلام مع امراة فرعون تبدأ بالمراودة وتتنهي بالسجن ولسنا بصدد رواية القصة القية لكن اردنا من خلال نسلسل احداثها نتعرف على ( خصائص السجن ) وانواعه : ففي النص الأول : (( واستبقا الباب وقدت قميصه ....)) فبعد حدوث المراودة ورؤية يوسف عليه السلام برهان ربه ، اذ اسند الاستباق اليهما معا في ضمير واحد وهذا دليل على انتراكهما في ذللك بصورة متساوية وجاءت صيغة ( استنقا ) لتشير الى الجها المبذول من الطرفين مع اختلاف نيتهما فهو عليه السلام كان لفتح الباب والخروج وهي لهنع فتح الباب وابفاءه موصدا وعدي الفعل دون

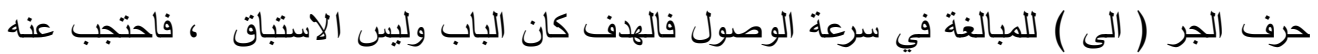
فعل المعصية بمجئ العزيز لم يكن من امراة العزيز الا ان تسعى إلى المكر والخداع منظاهرة بالعفة

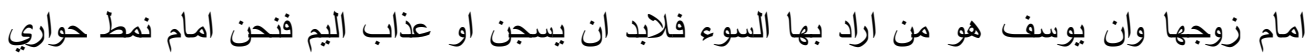
خارجي قائم على السؤال الذي يعد وعاء لغوي تفرغ فيه الاطراف المتحاورة مشاعرها وانفعالاتها ويبرز حضوره الاكبر في انتاج دلالات النص وتقايم حيثيات المضامين الحوارية ، فاستئناف الكلام بهذه الطريقة دون ان تتعلثم تخيل للمتلقي انها على الدق فافرغت الكلام في قالب كلي لياخذ صيغة القانون وليكون قاعدة لايعرف المقصود منها فلايسع المتلقي الا الاقرار لها - كأن المنلقي يسأل :

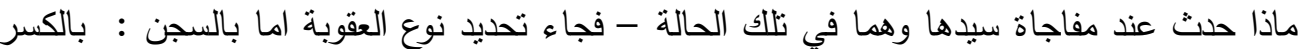
اي المكان الذي يسجن فيه ، فلم برد من السجن هنا العقوبة التي تقع على سبيل التعزير على فلى لقاه 
العدد الحادي والأربعون

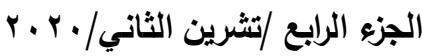

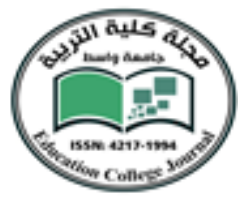

المعاصي أو لدرء الثبهات وانما المكان الذي يحبس فيه ، ويستمر الحوار برد يوسف او قوله:

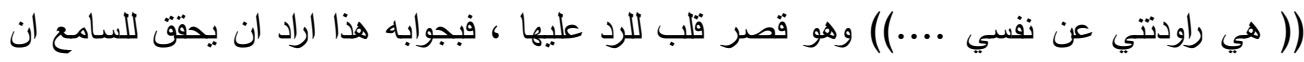

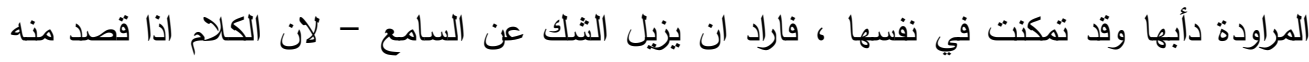
الاثبات فان تقديمه اولى من تاخيره وذلك لاسناد الكلام الواقع بعده إلى صاحب الظرف دارد دون غيره -

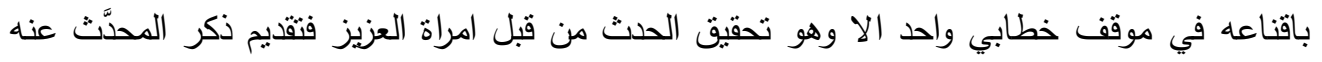

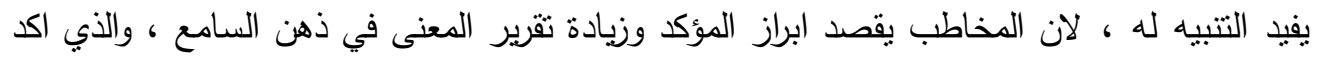

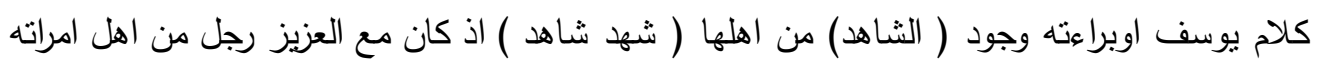

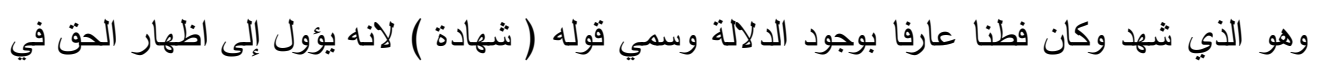

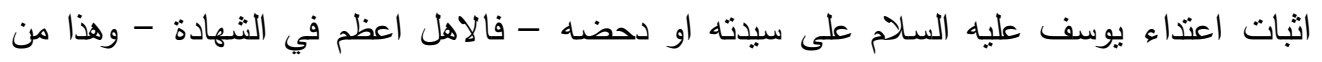

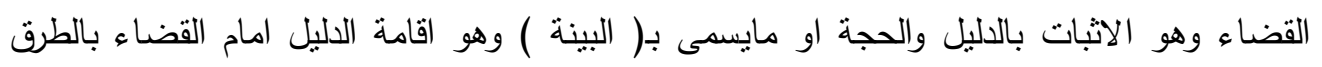

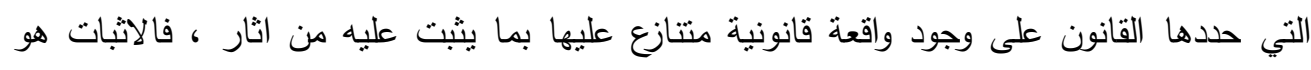

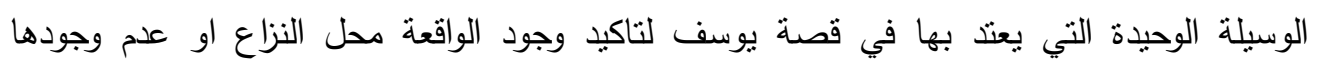

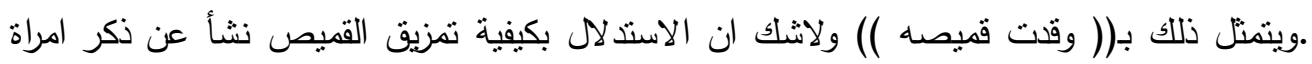

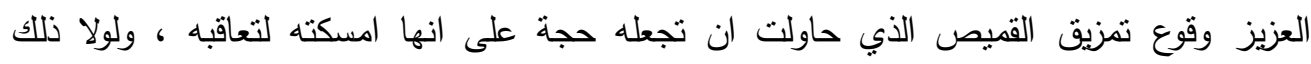

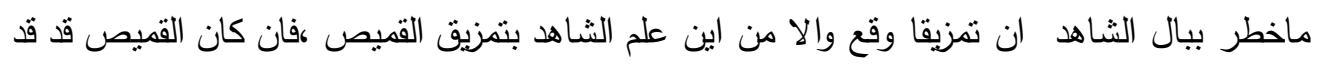

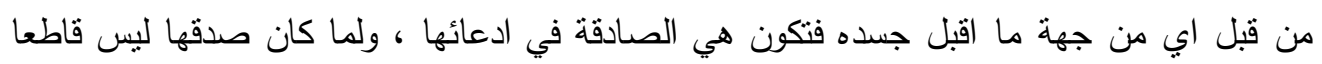

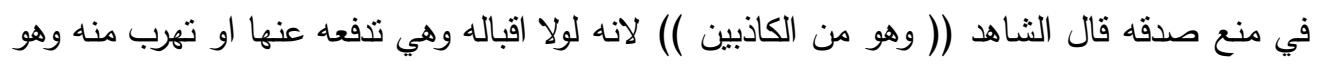

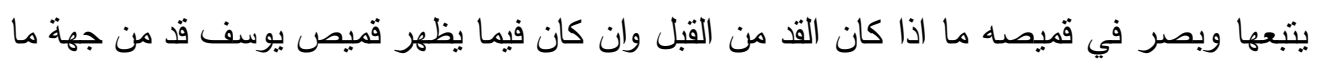
ادبر منه فتكون عندها هي الكاذبة ويكون هو من الصادقين :

قد من من قبل

وما يلاحظ من خلال الخطاطة أن آلية التضاد هي أكثر حضوراً في بنية الدكان وتوزيعها في النص النصا

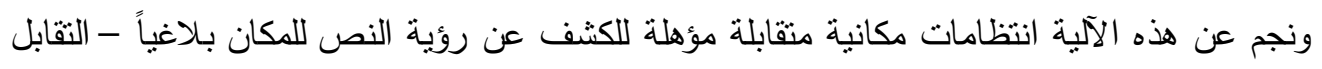

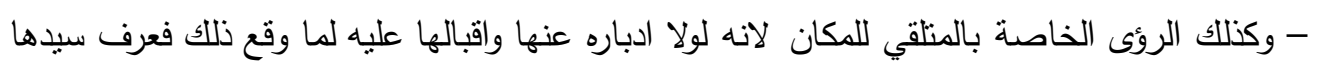

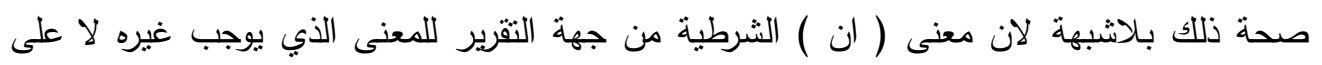


العدد الحادي والأربعون

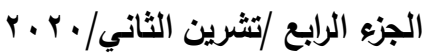

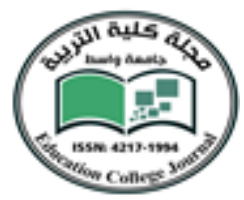

الثك، وقدم امارة صدقها لانه مما تحبه سيدها ، فهو من الظاهر اهتمام بها وفي الحقيقة تقدير لكذبها مرتين الاول باللزوم والثانية بالمطابقة ، فلما راى الثاهد قميصه قطع بصدقه وكذبها والظاهر ان الشاهد كان يظن صدقها فاراد ان يقيم دليلا على صدقها فوقع العكس ذلك كرامة ليوسف عليه السلام ، وما هذه الاتجاهات والمسافات الاّ مقاييس مكانية تحفظ للكائن في الدكان نوازنه الروحي فيه وتحميه من الضياع منلما تحفظه المقاييس الزمانية من فقدان الاحساس بالزمن. وليس هذا فحسب فقد بلغت جريت امراة العزيز ان تبرز للنسوة مراودتها ليوسف وترد مكرهن بمكر اقوى منه فارسلت اليهن واعت منكئا وامرت يوسف بان يخرج على النسوة وهذا يدل على انها اجبرته على نلك وابقته في البيت مع خروج زوجها لتحقق ماتريد من المكر من النسوة وعندما خرج عليهن انبهرن بجماله وقطعن ايديهن بدل الفاكهة وقد وجدت امراة العزيز فيما حلث ..... لها فاخبرت النسوة بان الذي راينه لاموها عليه ، فاعترفت بمراودتها من ثم امرته بفعل نلك والا ( بسجن ) ويكون من الصاغرين ، اذ انها نوعدت يوسف بالسجن بالفعل المضارع المبني للمجهول والمؤكد بلام القسم ونون التوكيد النقيلة وجيء بالفعل دون الاسم ليكثف عما في خبيئة نفسها بانها لاتريد له سجنا دائما

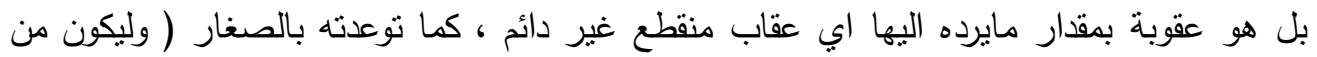
الصاغرين ) الذي جاء مسبوقا بفعل الكينونة المؤكد بنون النواكيد الخفيفة ، ويطالعنا هنا اعجاز

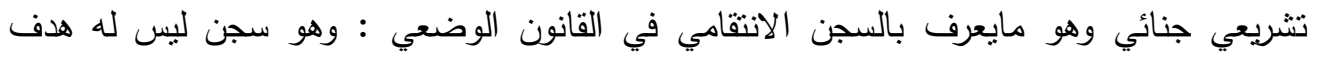
معقول اطلاقا الا ان الجبارين والظلمة - والمتمثل هنا بامراة العزيز - اذ بحمل هؤلاء حقد اعمى في

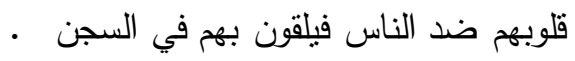
وتستمر المحاورة لكن هذه المرة في حوار يدور بين يوسف وخالقه في حوار احادي توجه فيه يوسف برسالته الكلامية المتضمنة هومه إلى خالقه وهو متيقن بان الله يسمعه وييصره ، متاملا ان بستجيب

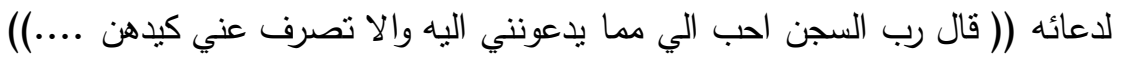

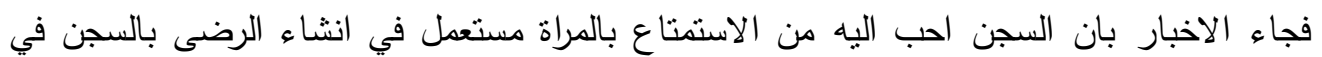
مرضاة الله تعالى والتباعد عن محارمه ، اذ لافائدة من اخبار من يعلم مافي نفسه فاسم التفضيل على لأل حقيقته ولا داعي إلى تاويله باسلوب المفاضلة ، كما انه عبر عما عرضته المراة بالموصولية لما في الصلة من الايماء إلى كون المطلوب حالة هي هي مظنة الطواعية ، لان تمالئ الناس على طلب

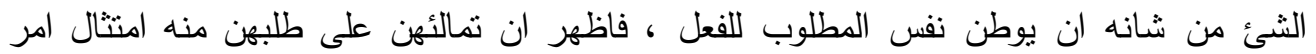
المراة لم بفل من صارم عزمه على الممانعة ، وجعل ذلك تمهيدا لثؤوال العصمة من الوقوع في شرك كيدهن فانتقل من ذكر الرضى بوعيدها إلى سؤال العصمة من كيدها بو ، ثم جاعت الاستجابة من الله 
العدد الحادي والأربعون

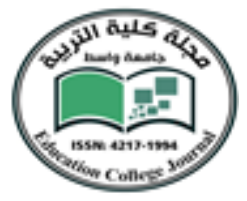

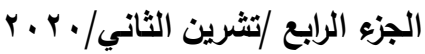

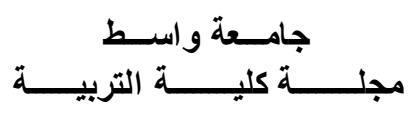

- سبحانه بتنفيذ الطلب وتحقيقه برد فعلي وصرف كيدهن عنه بصرف أثزه وذلك بان ثبته على لئل

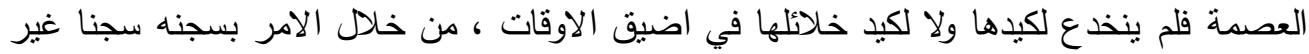
مؤجل المدة ( حتى حين ) والحين : يعني قدرا مبهما من الزمان طويلا اوقصيرا ، فالسجن هنا غير محد الددة ومن المنقق عليه ان الحبس غير المحدد المدة بعاقب به المجرمون ل... ومن اعتادوا ارتكاب جرائم القتل والضرب او تكرر منهم ارتكاب الجرائم الخطرة ويظل المجرم محبوسا حتى تظهر توبته وينصح حاله فيطلق سراحه والابقى محبوسا مكفوفا شره عن الجماعة حتى يموت ، فهو حبس لامدة له حتى الموت ينتهي بموت المحكوم عليه (يوسف) او عودته إلى امراة العزيز والقبول

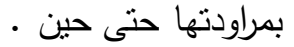
والحبس غير المحدد الددة نطبيق لنظرية العقوبة غير المحدودة التي عرفتها القوانين الوضعية في اواخر القرن التاسع عشر، وفي عصرنا الحاضر تعد هذه العقوبة من العناصر الجوهرية في تدابير

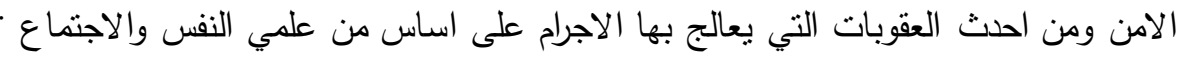

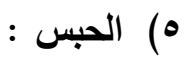

\begin{tabular}{|c|c|c|c|}
\hline السورة & رقمها & الاية & اللفظة \\
\hline المائدة & 1.7 & 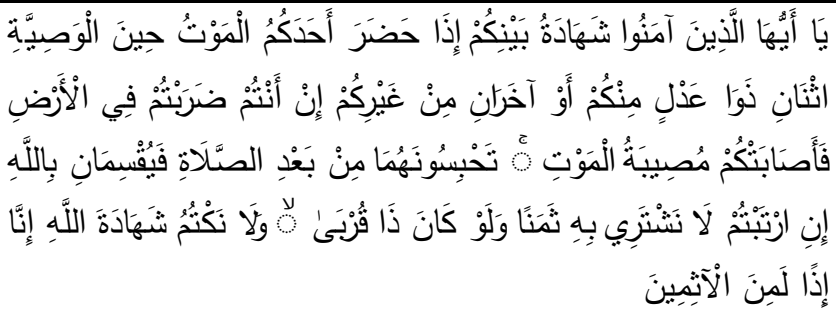 & تحبسونهما \\
\hline هود & $\Lambda$ & 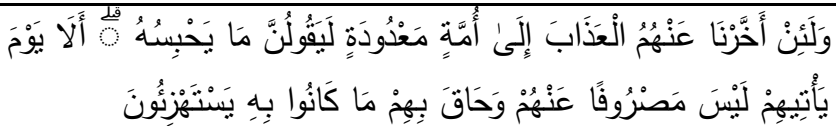 & يحبسه \\
\hline
\end{tabular}

الحاء والباء والسين يقال حبسه حبسا والحبس وماوقف “بوالمحبس -بكسر الباء- هو ما يبنى من

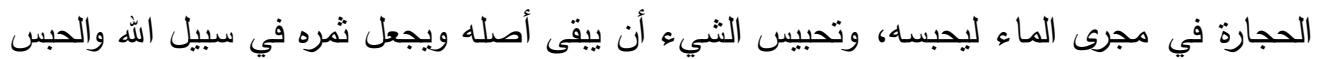
ضد النظلية، والحبسة في اللسان: هو تعذر الكلام عند إرادته، والمحبس الموضع الذي يحبس فيه

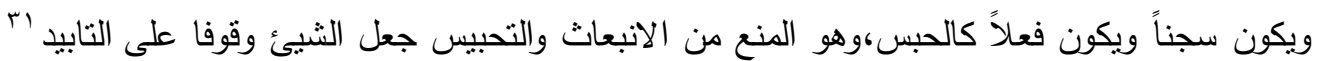

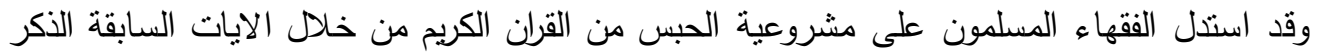


العدد الحادي والأربعون

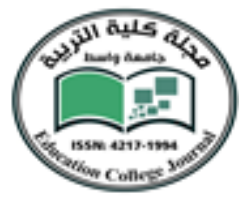

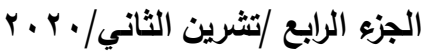

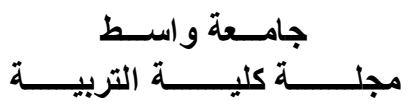

اذ يعد الحبس المرحلة الرابعة بعد التوقيف اذ تامر الجهة القضائية بحبس الممسوك على ذمة التحقيق وفي هذه المرحلة يكون الحبس مؤقتا لان الممسوك يروح ويجيئ إلى التحقيق وجلسات الاسنماع وهذه المرحلة تكون قبل صدور الحكم على الممسوك لذا هذه الفترة تكون مؤقتة وقصيرة وليس فيها

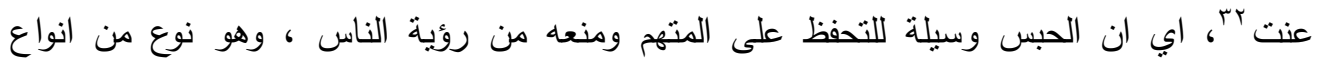
التعزيرات (( وقد يعزر الرجل بوعظه وتوبيخه والاغلاظ له .........وقد يعزر بالحبس ....وقد يعزر

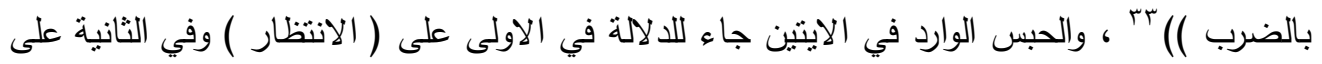
(المنع) وليس المقصود منه الحبس باكرا هاو اثقافه في قيد فالحبس ليس المقصود منه سكناه في السجن بل المراد منعه من التصرف المعتاد فالحكمة من مشروعية الحبس في الاسلام هو تحقيق المصالح ومن هذه المصالح ما ورد في سورة المائدة من احكام التوثق للوصية تحقيقا لاكمال الدين

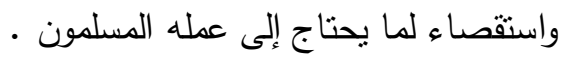
كما ان الحبس في الثريعة على نوعين حبس محدد المدة وحبس غير محدد المدةء ، وفي الآية وضع مقدار لزمن الحبس او نوقيتا لاحضار الثاهدين وامساكهما لاداء هذه الثهادة وهو - بعد الصلاة - اي قرب انتهاء الصحلاة والحبس هنا هو الامساك اي المنع من الانصراف اوالانتظار وهذا ما اوحى اليه المعنى باحالة خارجية في حديث عنبان بن ماللك فغذا على رسول الله وابو بكر إلى ان

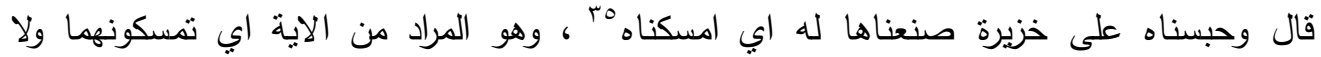
تتركونهما يتحملا الوصية ، فالنص يبدأ باستئناف ابتدائي لثرع احكام التوثق للوصية لانها من جملة

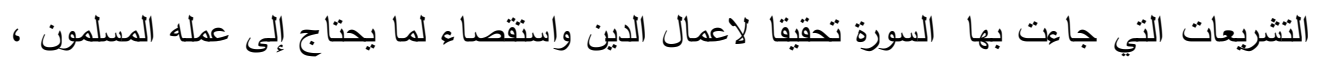
فالوصية كانت معروفة قبل الاسلام فلم يكن شرعها احداث شيئ غير معروف ، لكن الوصية هنا جاءت مقرونة ببيان التوثق لها اهتماما بها لذلك احتيج فيها إلى مزيد من البينة لتلقي الحكم بقوله يا ايها ولعل خصوصية ورود هذه الصيغة في ابتداء هذه الاية لقرتها على اثارة مزيد من التشويق والانفعال والترقب لما سيكون بعدها لانها تحقق بعد نفسيا نتج من طول الاداة وتتوعها ومن ثم طول المسافة بين المنادى وتراخي الزمن فيها فضلا عن ان هذه الصيغة ابلغ واخص من غيرها لانها تكون تاكيدا لمعنى النداء ، مخصصا الحق سبحانه بعد النداء المسلمين بوصف محبب إلى نفوسهم مشعر بقرب المنادى من المنادي لما فيه من تعظيم وتشريف لمكانتهم عنده تعاليى فضلا عن كونه تتبيها وتمهيدا لما سياتي ذكره من مسائل في اصول الدين ويتمنل هنا بتوثيق الوصية لما في هذا الامر من

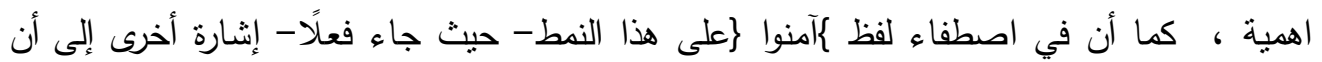
إيمانهم لا يزال فعلاً، وأنه ما يزال فيهم بقية من غفلة وليدخل فيه عموم من دخلوا في الإيمان، وليس 
العدد الحادي والأربعون

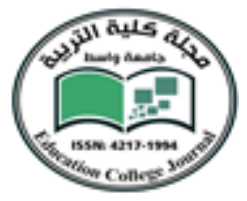

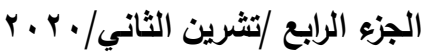

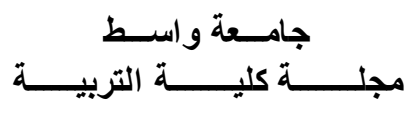

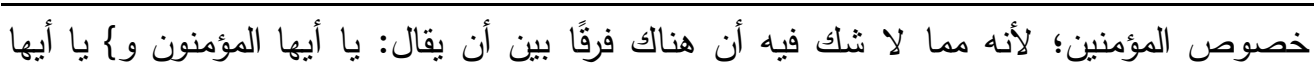

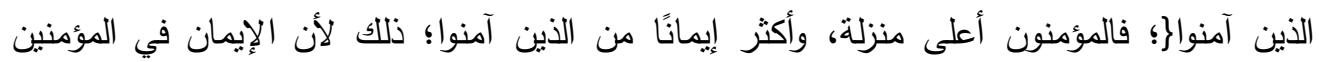

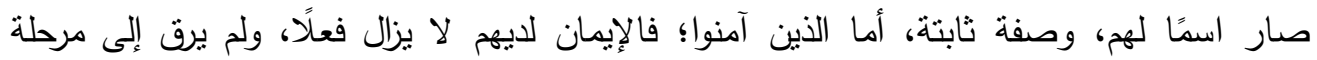
الثبوت

فإن النداء عليهم تشريف لهم بتعريفهم بخير صفاتهم. وزد على ذلك أن النداء عليهم صادر عن الحق سبحانه وتعالى وليس هناك وسيط بينه وبينهم، وفي ذللك أيضا من التشريف ما فيه وهذا التكليف والتنكير، والتشريف المحتَضَن في رحم النظم متتاسق

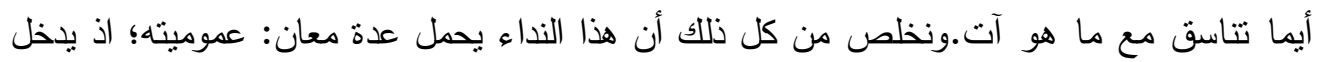
فيه القريب والبعيد، تنكير المنادى بما التزم به من إيمان؛ ليكون دافعًا له إلى التسليم والطاعة.

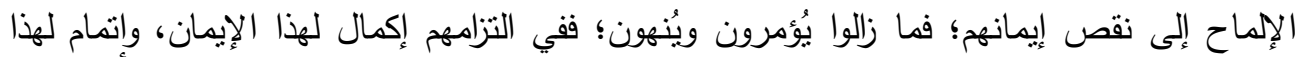
البناء.

إرفاق كل ذلك بالتشريف، والتقدير ، فهم موصولون بالله تعالى،لمباشرته ندائهم

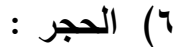

\begin{tabular}{|c|c|c|c|}
\hline 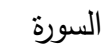 & 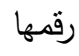 & الاية & 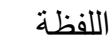 \\
\hline الانعام & 1 r & ((وقالوا هذه انعام وحرث حجر لايطعمها ....()) & حجر \\
\hline الحجر & $\wedge$. & (( ولقد كذب اصحاب الحجر المرسلين )) & حجر \\
\hline 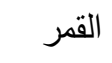 & $\circ$ & (( هل في ذلك قسم لذي حجر ...)) & حجر \\
\hline 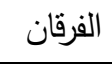 & rt & (( لابشرى يومئذ للمجرمين ويقولون حجرا محجورا ......)() & حجرا \\
\hline الفرقان & or & ((وربائبكم اللاتي في حجوركم من نسائكم ......)) & 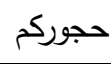 \\
\hline 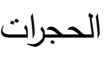 & $\varepsilon$ & (( ان الذين ينادنك من وراء الحجرات اكثرهم لايعقلون )) & 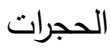 \\
\hline
\end{tabular}

الحجر : الحجر لغة المنع. يقال: حجر عليه حجرا منعه من التّصرّف فهو محجور عليه،,وتاتي

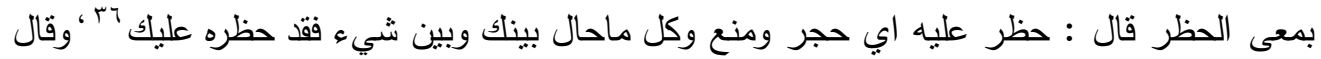
المطرزي في كتابه ( المغرب) الهنع بالافساد فقال : والحجر الدنع ومنه حجر عليه القاضي اذاذا منعها 
العدد الحادي والأربعون

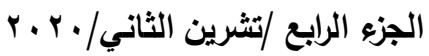

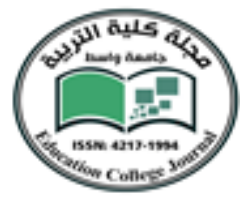

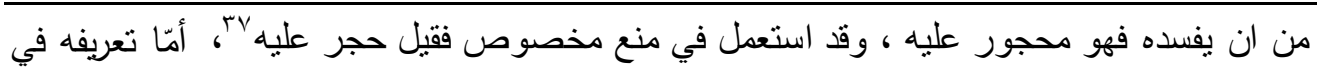

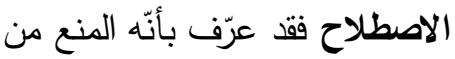

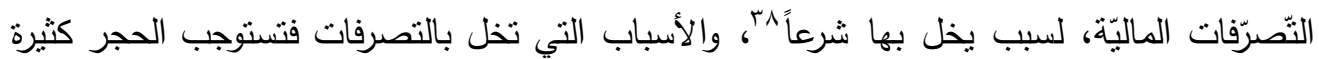

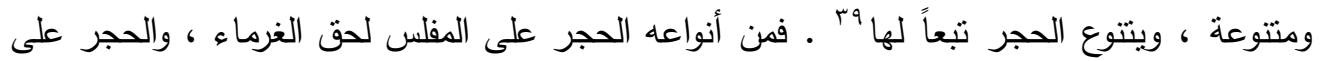
المريض مرض الموت لحق الورثة ، والحجر على الصغير والمجنون محافظة على مالهما ، والحجر

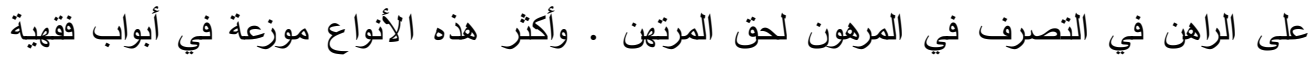

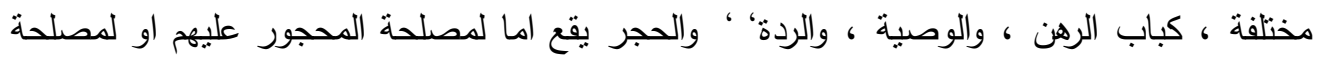

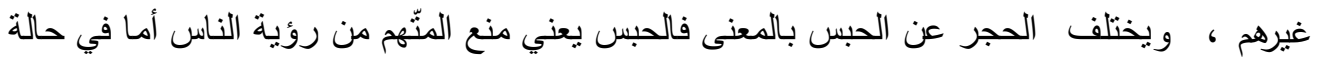

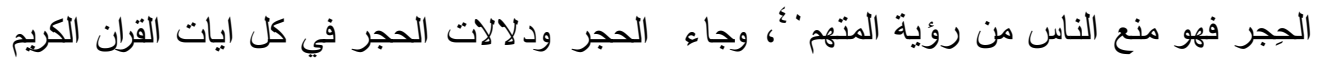

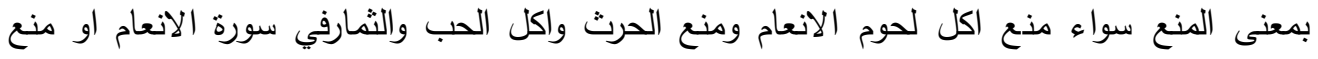
العقل لصاحبه من ارتكاب ملاينبغي سورة القمر والاستعاذة من وقوع الخطر سورة الفرقان او الحضانة والكفالة سورة الحجرات ، وما يقع ضمن منظومة الحبس والمعنى الحسي للحجر هو ماورد في سورة الحجر الاية ( •^) (( ولقد كنب اصحاب الحجر المرسلين واتيناهم اياتتا فكانوا عنها معرضين وكانوا ينحتون من الجبال بيوتا امنين ،،،،؛)) وقوله نعالى : (( ان الذين ينادنك من وراء الحجرات اكثرهم لايعقلون )) فاصحاب الحجر هم ثمود كانوا ينزلون الجِر - بكسر الحاء وسكون

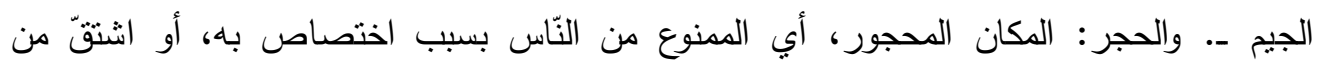

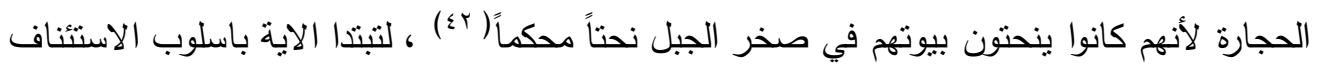
لنسلية الرسول صلى الهه عليه وسلم ناشئ عن قوله: : لا تأس عليهم ولا بعظم عليك أنهم كذبوك فقد

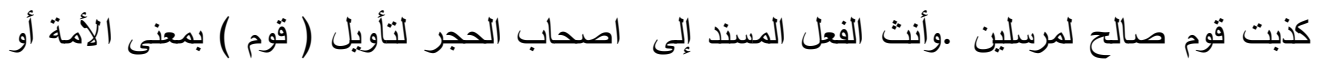
الجماعة وذلك قياس في كل اسم جمع لا واحد له من لفظه إذا كان للآدمي منل نفر ورهط ، فأما

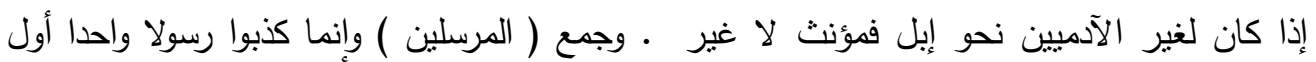

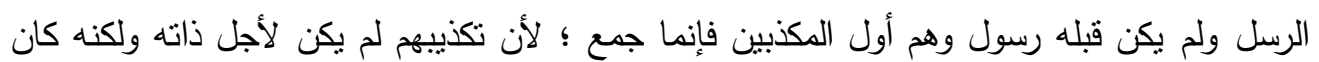
لإحالتهم أن يرسل اله بشرا وأن تكون عبادة أصنامهم ضلالا فكان تكذيبهم إياه مقتضيا تكذيب كل

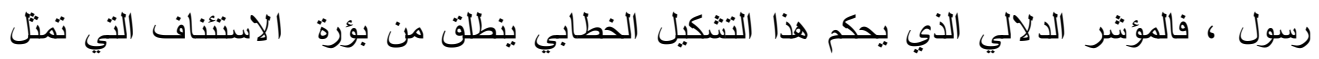
المحور الذي يسنقطب الأكانيات الدلالية الاضافية التي يضفيها النص على المعنى نتيجة استدعاء المفردات لبعضها وتعاقب الوحدات الدالة ليكون اشارة اولية على اعلام المتلقي بما يجول في ذهن

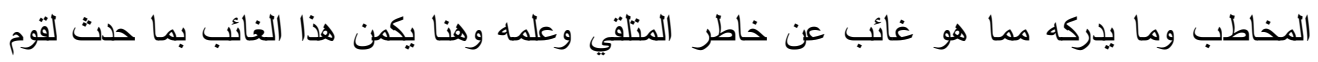


العدد الحادي والأربعون

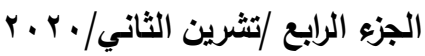

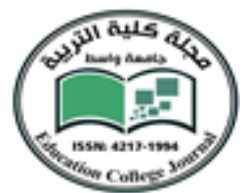

صالح عندما كذبوا صالح عليه السلام وما وقع عليهم من عذاب الصيحة رغم انهم يسكنون في بيوت منحوتة من الجبال حصينة ممنوعة قوية لكن ما شيء من هذا وفاهم من الصيحة الني تلحقهم وهم في جوف الصخر ، فهذه اللمحة الخاطفة من الامن في البيوت الامنة الحصينة في صلب الجبال الى العذاب بالصيحة تلمس قلب المنلقي لمسا عنيفا وتحوله من كيان سلبي في السيرورة الخطابية

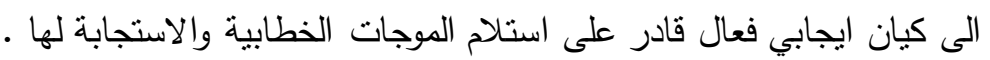

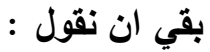

العقوبة هي حجر الزاوية في أي منظومة قانونية، شرعية كانت أم وضعية؛ لأنها أداة تحقيق العدالة وتحويلها من إطارها النظري إلى إجراءات واقعية ملموسة، والغرض منها تأديب الدذنب، وردع غيره، وصيانة نظام الجماعة، وورود الالفاظ الدالة على الحبس في القران بتنوعها الدلالي اتاح لنا التعامل معها داخل النص بلاغيا، اذ تارجحت الفاظ هذه المنظومة بين الحقيقة والمجاز والتي بدورها

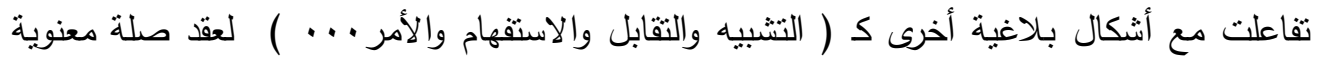
داخل السياق واستخلاص الخواص الجزئية التي يؤثر كل منها في الآخر لأداء المعنى المقصود ، ومن هنا تاني الدعوة إلى أن برتكز البحث البلاغي في تتاوله النصوص على ما تبرزه القيم البلاغية

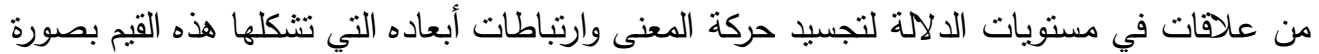

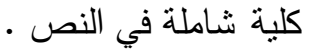
المصادر : (المان

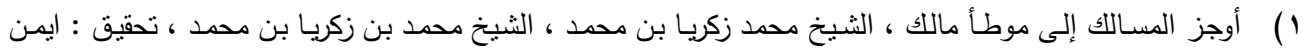

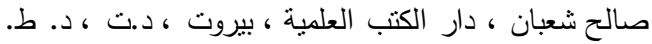

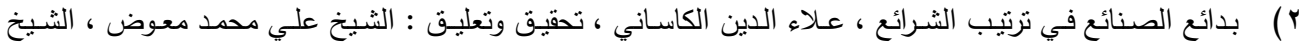

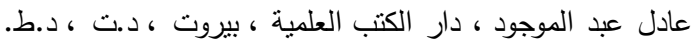

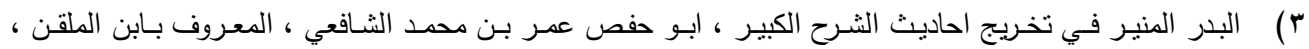

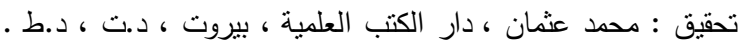

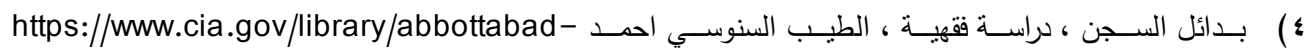
compound/48/486397C54D49DD77E48D4586A98EC6DF •) التحرير والتتوير ، الطاهر بن عانور ، دار سحنون ، تونس ، د.ت ، د. ط.

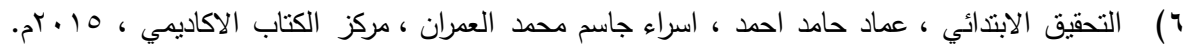

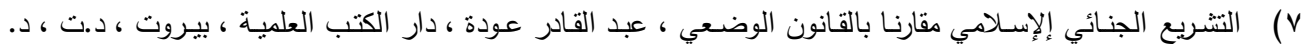


العدد الحادي والأربعون

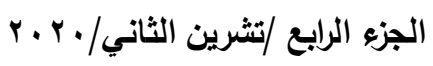

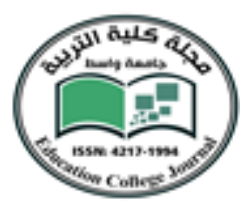

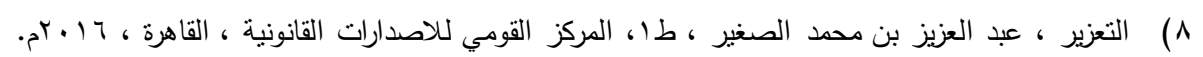

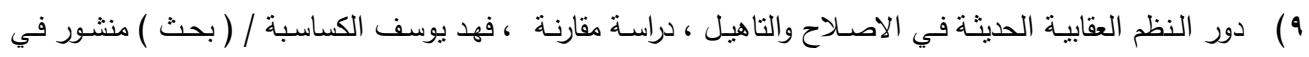

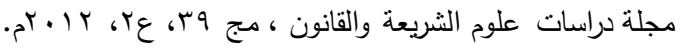

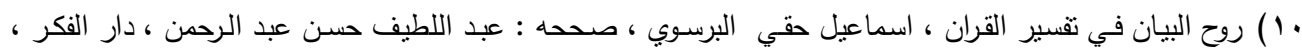

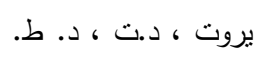

11) صحيح البخاري ، ابو عبد الهمحمد بن اسماعيل البخاري ، دار الكتب العلمية ، بيروت ، د.ت ، د. د. ط.

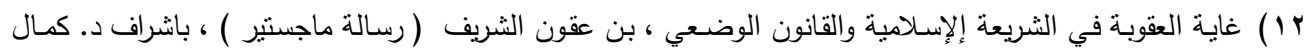

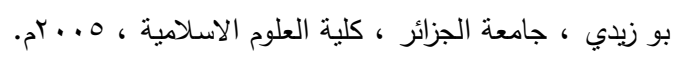

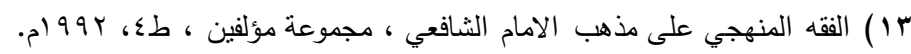

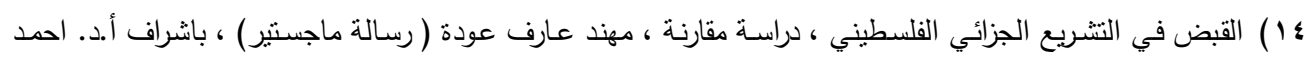

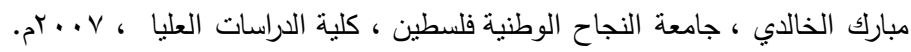

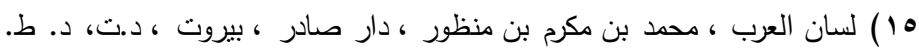

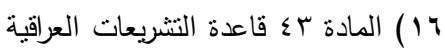

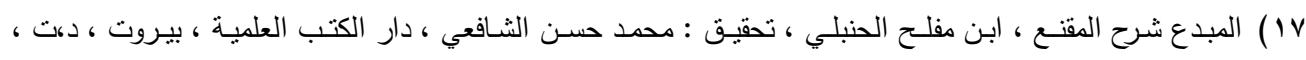

11 11 ) مجموعة الفناوى لثيخ الاسلام ابن تثمية ، ابن تيمية

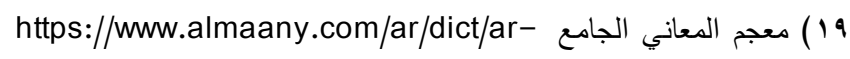
(Y.

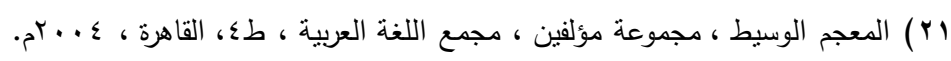

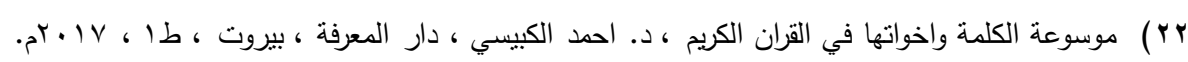

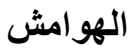

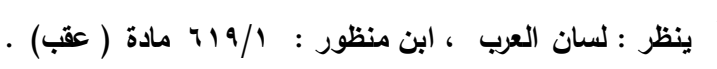

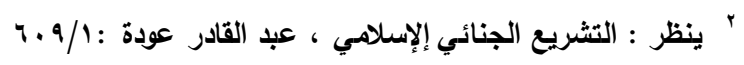

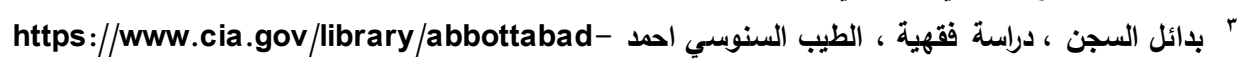
compound/48/486397C 54D49DD77E48D4586A98EC6DF " ينظر : غاية العقوبة في الثريعة إلإسلامية والقانون الوضعي ، ابن عقون الثريف /9 1، ( رسالة ماجستير )

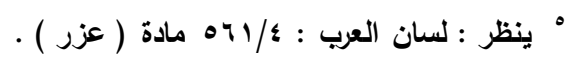

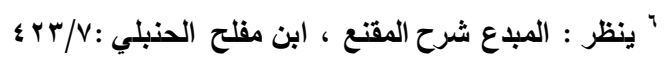

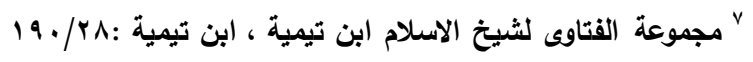

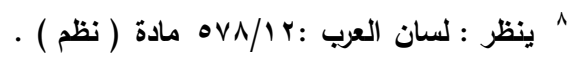

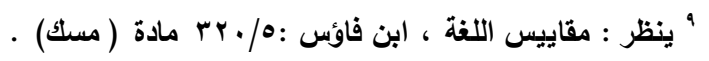


العدد الحادي والأربعون

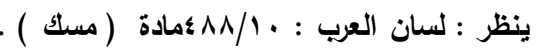

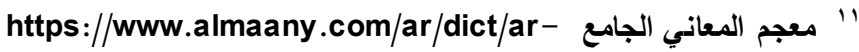

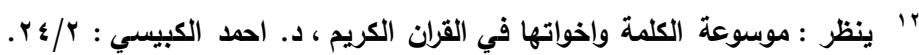

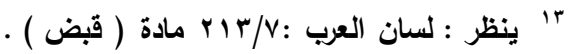

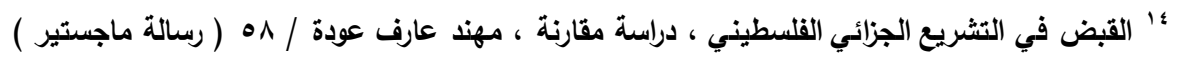

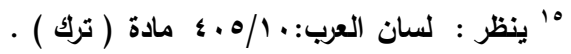
17 14

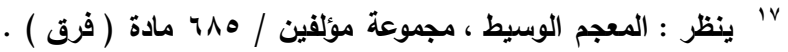

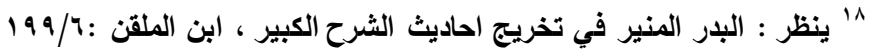

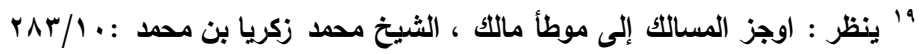

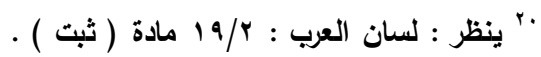

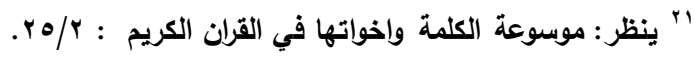

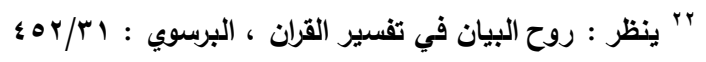

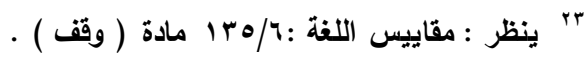

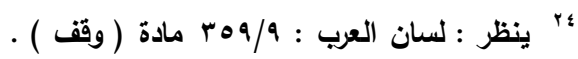

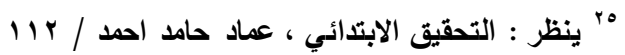

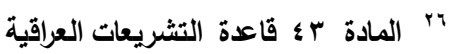

http://iraqld.hjc.iq:8080/LoadArticle.aspx ?SC=251020077636747 rv ينظر : مقاييس اللغة :rv/rv

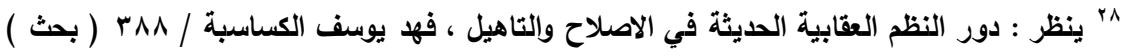

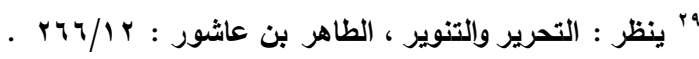

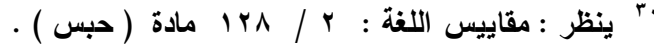

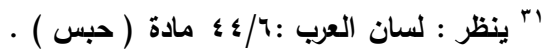

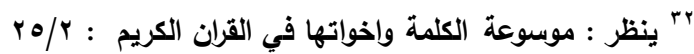

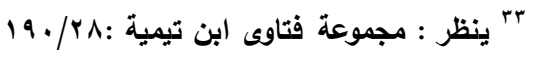

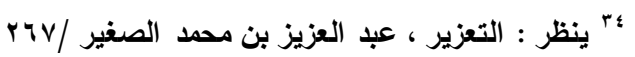

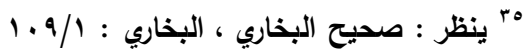

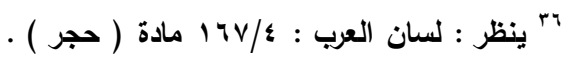

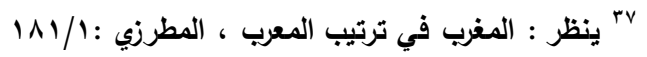

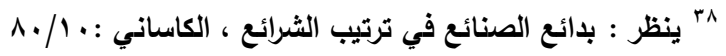

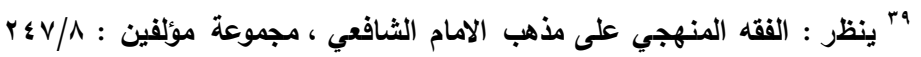

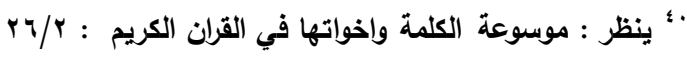

